\title{
Gravitational, erosional and depositional processes on volcanic ocean islands: Insights from the submarine morphology of Madeira Archipelago
}

\author{
Quartau Rui 1, *, Ramalho Ricardo S. 2, 3, 4, Madeira Jose 2, Santos Ruben 1, Rodrigues Aurora 1,
} Roque Cristina ${ }^{2,5}$, Carrara Gabriela ${ }^{6}$, Da Silveira Antonio Brum ${ }^{2}$

1 Inst Hidrog Marinha, Div Geol Marinha, P-1200615 Lisbon, Portugal.

2 Univ Lisbon, Fac Ciencias, Inst Dom Luiz, P-1749016 Lisbon, Portugal.

3 Univ Bristol, Sch Earth Sci, Bristol BS8 1RJ, Avon, England.

${ }^{4}$ Columbia Univ, Lamont Doherty Earth Observ, Palisades, NY 10964 USA.

${ }^{5}$ Estrutura Missao Extensao Plataforma Continental, P-2770047 Paco De Arcos, Portugal.

${ }^{6}$ Emilia Romagna High Technol Network, PROAMBIENTE Consortium, I-40129 Bologna, Italy.

* Corresponding author : Rui Quartau, email address : rui.quartau@hidrografico.pt

\begin{abstract}
:
The submarine flanks of volcanic ocean islands are shaped by a variety of physical processes. Whilst volcanic constructional processes are relatively well understood, the gravitational, erosional and depositional processes that lead to the establishment of large submarine tributary systems are still poorly comprehended. Until recently, few studies have offered a comprehensive source-to-sink approach, linking subaerial morphology with near-shore shelf, slope and far-field abyssal features. In particular, few studies have addressed how different aspects of the subaerial part of the system (island height, climate, volcanic activity, wave regime, etc.) may influence submarine flank morphologies. We use multibeam bathymetric and backscatter mosaics of an entire archipelago - Madeira - to investigate the development of their submarine flanks. Crucially, this dataset extends from the nearshore to the deep sea, allowing a solid correlation between submarine morphologies with the physical and geological setting of the islands. In this study we also established a comparison with other island settings, which allowed us to further explore the wider implications of the observations. The submarine flanks of the Madeira Archipelago are deeply dissected by large landslides, most of which also affected the subaerial edifices. Below the shelf break, landslide chutes extend downslope forming poorly defined depositional lobes. Around the islands, a large tributary system composed of gullies and channels has formed where no significant rocky/ridge outcrops are present. In Madeira Island these were likely generated by turbidity currents that originated as hyperpycnal flows, whilst on Porto Santo and Desertas their origin is attributed to storm-induced offshore sediment transport. At the lower part of the flanks $(-3000$ to $-4300 \mathrm{~m})$, where seafloor gradients decrease to $0.5^{\circ}-3^{\circ}$, several scour and sediment wave fields are present, with the former normally occurring upslope of the latter. Sediment waves are often associated with the depositional lobes of the landslides but also occur offshore poorly-developed tributary systems. Sediment wave fields and scours are mostly absent in areas where the tributary systems are well developed and/or are dominated by rocky outcrops. This suggests that scours and sediment wave fields are probably generated by turbidity currents, which
\end{abstract}


experience hydraulic jumps where seafloor gradients are significantly reduced and where the currents become unconfined. The largest scours were found in areas without upslope channel systems and where wave fields are absent, and are also interpreted to have formed from unconfined turbidity currents. Our observations show that tributary systems are better developed in taller and rainy islands such as Madeira. On low-lying and dry islands such as Porto Santo and Desertas, tributary systems are poorly developed with unconfined turbidite currents favouring the development of scours and sediment wave fields. These observations provide a more comprehensive understanding of which factors control the gravitational, erosional, and depositional features shaping the submarine flanks of volcanic ocean islands.

\section{Graphical abstract}

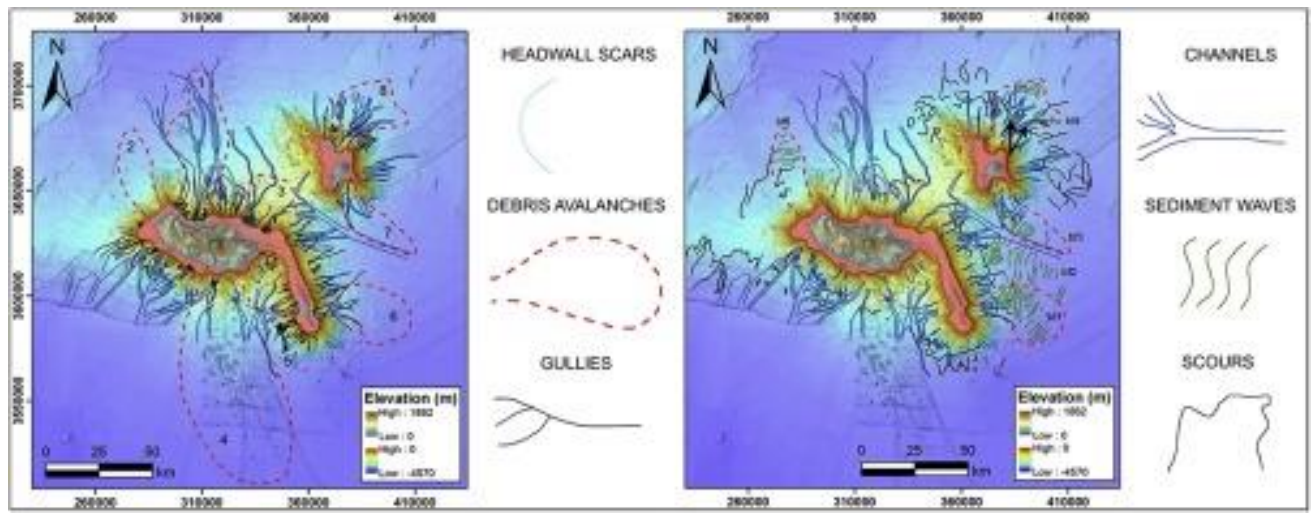

\section{Highlights}

Source-to-sink approach to study the submarine flanks of Madeira Archipelago. Islands subaerial characteristics control the development of submarine flanks. A network of submarine gullies and channels dissects the islands' flanks. Their origin is related to hyperpycnal or storm-induced sediment flows. Wave and scour fields form downslope of channels by unconfined turbidite currents.

Keywords : volcanic ocean islands, Madeira Archipelago, landslides and debris avalanches, gullies and channels, scour and wave fields 


\section{Introduction}

The main volume of volcanic islands lies hidden beneath the sea and consequently their submarine flanks are far less studied than their accessible subaerial parts. The study of the submarine pedestals of volcanic islands is of great significance, because it can significantly improve our knowledge of island evolution, particularly if integrated with information on the development of subaerial edifices (Moore et al., 1989; Masson et al., 2002; Leat et al., 2010; Quartau and Mitchell, 2013; Saint-Ange et al., 2013; Quartau et al., 2015a). The advent of modern seafloor surveys during the 1980's, with sidescan and multibeam sonars, allowed the discovery of large-scale landslides (Moore et al., 1989; Masson et al., 2002), canyons and turbidite systems (Krastel et al., 2001; Sisavath et al., 2011), and sediment wave (Wynn et al., 2000a; Hoffmann et al., 2008) and scour fields (Hoffmann et al., 2011). Despite the vast range of published works, however, few comprehensive source-to-sink studies on ocean island volcanoes have focused on the development of their submarine flanks (e.g., Saint-Ange et al., 2013).

Moreover, whether based on drilling (Schmincke and Sumita, 1998) or on the characterization of their submarine morphologies, most studies focus on a single island (Saint-Ange et al., 2013) or on a single process (Hunt et al., 2014). Consequently, works rarely relate subaerial conditions and shelf processes with the development of deeper submarine morphologies.

In this study, we make use of novel multibeam bathymetric and backscatter mosaics of an entire archipelago - which crucially extend from the nearshore to the abyssal plains - to gain a comprehensive insight on the origins of several gravitational, erosional and depositional features shaping the submarine flanks of volcanic islands. Furthermore, a correlation with the diverse physiographic conditions and geological evolution of each of the islands, allowed us to understand how these characteristics conditioned their present-day submarine flank 
morphologies. The case study of Madeira Archipelago is therefore particularly elucidative providing a unique insight onto the evolution of the submarine flanks of reefless oceanic volcanoes.

\section{Regional Setting}

Madeira Archipelago is located in the NE Atlantic, $\sim 1000 \mathrm{~km} \mathrm{SW}$ of the Iberian Peninsula (Figure 1). It comprises the islands of Madeira $\left(737 \mathrm{~km}^{2}\right)$, Porto Santo $\left(42 \mathrm{~km}^{2}\right)$, and Desertas $\left(13 \mathrm{~km}^{2}\right)$. The island edifices are the result of intra-plate volcanism on the slow-moving Nubian plate, leading to a hotspot track extending to the NE (Geldmacher et al., 2000). Although administratively included in Madeira Archipelago, the Selvagens Islands $\left(\sim 3 \mathrm{~km}^{2}\right)$ constitute, from the geological point of view, a distinct archipelago.

Madeira is the youngest island, with volcanism extending from $>7$ Ma to the Holocene (Geldmacher et al., 2000; Mata et al., 2013; Ramalho et al., 2015). Subaerial Madeira extends 58 $\mathrm{km}$ in the WNW-ESSE direction and has an average width of $15 \mathrm{~km}$ (annotation 1 in Figure 2). The island is an elongated shield volcano, which despite being highly dissected, is largely above $1200 \mathrm{~m}$, reaching a maximum elevation of $1862 \mathrm{~m}$ at Pico Ruivo. This configuration of the island constitutes a barrier to the dominant NE trade winds, causing higher precipitation in the north-facing slopes (Prada et al., 2005). Notwithstanding this asymmetry, Madeira has a welldeveloped and deeply incised subaerial drainage system on both flanks, mostly oriented N-S, descending on average from $1200 \mathrm{~m}$ to sea level in only $6 \mathrm{~km}$. The annual precipitation on Madeira varies from $600-800 \mathrm{~mm}$ on the south coast to $1500-2000 \mathrm{~mm}$ on the north, reaching $3000 \mathrm{~mm}$ in the higher ranges (Baioni, 2011). Rainfall is often temporally concentrated making 
the island very prone to flash floods and subaerial landslides (Baioni, 2011). During the flashflood of $20^{\text {th }}$ February 2010 , rainfall attained $500 \mathrm{~mm}$ in a single day and the volume of solid discharge deposited in the Funchal urban area reached $250000 \mathrm{~m}^{3}$ (Lira et al., 2013).

The Madeira-Desertas system is considered to be the expression of two arms of a volcanic rift intersecting at an angle of $\sim 110^{\circ}$ and surrounded by the $200 \mathrm{~m}$ isobath (Klügel et al., 2009). The Desertas Islands (from north to south: Ilhéu Chão, Deserta Grande and Bugio) correspond to the $50 \mathrm{~km}$-long NNW-SSE trending arm, although their subaerial expression is only $22 \mathrm{~km}$ long (annotation 2 in Figure 2). Effectively, these islands are presently reduced to very narrow ridges $(<2 \mathrm{~km})$, featuring subaerial aspect ratios (height/width) between 0.2 and 0.6 , clearly the result of strong wave erosion and landsliding. Volcanism leading to the formation of Desertas shows similarities with Madeira's, although its volcanic activity ceased 1.9 Ma ago (Schwarz et al., 2005).

Porto Santo is separated from the Madeira-Desertas system by a $30 \mathrm{~km}$ wide and $2500 \mathrm{~m}$ deep channel (annotation 3 in Figure 2 and Figure 3). It is a much older island (with volcanic activity restricted to 14-10 Ma), being significantly eroded and lying below $517 \mathrm{~m}$ of elevation (Schmidt and Schmincke, 2002). It has an average annual precipitation $<400 \mathrm{~mm}$, typical of a semi-arid climate. Streams have an ephemeral character and only flow after heavy rainfall (Ferreira and Cunha, 1984).

\section{Data and Methods}

The comprehensive multibeam mapping around Madeira Archipelago was performed by the Portuguese Hydrographic Institute (IH) under the programs EMEPC (Estrutura de Missão 
para a Extensão da Plataforma Continental) and SEDMAR (Sedimentary environment of the Madeira Archipelago). The intermediate and deeper bathymetry was acquired by IH, between 2005 and 2014, using the Kongsberg EM710 and EM120 multibeam echo-sounders aboard R/Vs "Almirante Gago Coutinho" and "D. Carlos I". Multibeam bathymetry of the southern shelves of Madeira and Porto Santo was also acquired by IH during coastal management projects, between 2003 and 2008, with the Kongsberg EM3000 and EM3002 echo-sounders onboard survey launches. Multibeam surveys were mostly DGPS-positioned and processed using Caris software Hips \& Sips. Corrections were mostly done by manual editing of data before 2011 and with CUBE (Combined Uncertainty and Bathymetric Estimator, Calder and Mayer, 2003) after 2011. Bathymetric data acquired above $-200 \mathrm{~m}$ included tide corrections based on published tidal charts. High-resolution digital elevation models were produced with cell-size varying from $2 \mathrm{~m}$ in areas $<-100 \mathrm{~m}$ to $250 \mathrm{~m}$ at $-4500 \mathrm{~m}$ (Figure 3). Radiometric and geometric corrections were also applied to the raw data with the Geocoder algorithm implemented in Fledermaus Pro to build backscatter strength mosaics (Figure 4). Single-beam bathymetry (grid-size of $\sim 230 \mathrm{x} \sim 190$ m), from the European Marine Observation and Data Network (EMODnet) project, filled gaps between multibeam datasets.

The multichannel seismic reflection profile was acquired by IFREMER during the TORE-MADÈRE cruise (25th September - 20th October 2001), using a six- channel streamer at $5 \mathrm{~m}$ depth and two GI airguns (105/105 and 45/45 cu in.) at a surface speed of 10 knots (Cornen et al., 2003). Seismic lines were processed using a spherical divergence correction, a band bass filter, and stacking of the six channels to improve the signal/noise ratio. 


\section{Results}

The features identified on the multibeam bathymetry, backscatter and seismic reflection datasets allowed mapping the submarine flanks of the archipelago in detail, from the coastline down to $-4500 \mathrm{~m}$. Seafloor interpretation was divided into gravitational (headwall scars of landslides and respective debris avalanches), erosive (gullies, channels and scour fields), and depositional morphologies (sediment wave fields).

\subsection{Large landslides}

\subsubsection{NW Madeira}

This landslide exhibits the largest headwall scar ( $22 \mathrm{~km}$ in length) of all the identified shelf edge failures, and is mimicked by an adjacent concave coastline (annotation 1 in Figure 5 and Table 1). It was previously identified based on onshore geomorphology and named "São Vicente landslide" (Brum da Silveira et al., 2010a). The scar is incised by small gullies (black lines in Figure 5), a few hundred-metres wide and up to $10 \mathrm{~km}$ in length, commonly having a Vshaped section. They are commonly organized in parallel networks, slightly converging downslope into three wider and flat-bottomed channels without a marked headwall. The gullies are restricted to the chute area and their transition into the channels occurs at $\sim-2000 \mathrm{~m}$, corresponding to an abrupt change of gradient. The three main channels are each around $60 \mathrm{~km}$ in length, with widths varying from 1 to $5 \mathrm{~km}$. They divert inside a somewhat lobate area with an irregular seafloor punctuated by some large blocks between $-3000 \mathrm{~m}$ and $-4000 \mathrm{~m}$. The blocks are irregular, with varying sizes, from a few hundred metres to a few kilometres in diameter. The largest is $3 \mathrm{~km}$ in diameter and rises $0.6 \mathrm{~km}$ above the surrounding seafloor. The seismic line Torem060 (Figure 6) crosses these channels and shows an irregular and sometimes hyperbolic 
112 seafloor reflection between shots 2350 and 3250 (Figure 6). This irregular surface corresponds in

113 depth to a single chaotic seismic unit ( $250 \mathrm{~ms}$ thick), interpreted as a debris avalanche. Around

114 shot 2350 , this unit is abruptly replaced by a well-stratified unit along a plane dipping $\sim 20^{\circ}$ to the

115 NW. The three main channels widen and give way to a braided channel system only perceptible

116 in the backscatter imagery (Figure 4). Here, high backscatter values suggest the channel filling

117 by coarser sediments, dissecting normal pelagic sedimentation (seen in the seismic line as well-

118 defined and rhythmic reflections between shots 2000 and 2350).

\subsubsection{NNW Madeira}

This landslide is inferred by the slightly concave configuration of the shelf edge,

121 featuring a $\sim 8 \mathrm{~km}$ wide headwall scar and downslope by a somewhat lobate debris avalanche

122 deposit (annotation 2 in Figure 5 and Table 1). The surface of this deposit is dissected by scour

123 fields from 12 to $25 \mathrm{~km}$ of the scar, evolving to a sediment wave field that extends up to $43 \mathrm{~km}$

124 offshore (see sections 4.3 and 4.4 and Figure 7).

125

\subsubsection{NE Madeira}

This landslide is inferred by the concave configuration of the shelf edge, which features a $\sim 20 \mathrm{~km}$ wide headwall scar (annotation 3 in Figure 5 and Table 1). Onshore, the coastline mimics this concave configuration, exhibiting steep cliffs up to $700 \mathrm{~m}$ high. This landslide had been previously proposed by Geldmacher et al. (2000) and named "Porto da Cruz landslide" by Brum da Silveira et al. (2010a). The shelf break is incised by small gullies that form three main channels further offshore. 


\subsubsection{SE Madeira}

This landslide is inferred by the hummocky seafloor morphology that extends $\sim 100 \mathrm{~km}$

from the shelf break (annotation 4 in Figure 5 and Table 1). Some of these reliefs correspond to a NNW-SSE, $\sim 60 \mathrm{~km}$ long alignment of submarine volcanic cones, named as the "Funchal Volcanic Ridge” by Klügel and Klein (2006). However, within this $100 \mathrm{~km}$ strip, several features exhibit irregular shapes, typical of blocks from a large debris avalanche deposit. Onshore, the morphology corresponds to a wide amphitheatre. This feature has been interpreted as a subaerial scar of a flank collapse (named "Funchal landslide"), which has been covered by recent volcanism of the Upper Volcanic Complex (Brum da Silveira et al., 2010b; Ramalho et al., 2015). The shelf break is incised by small V-shaped gullies, a few hundred-metres wide and up to $2-3 \mathrm{~km}$ in length. These are generally organized in sub-parallel networks, slightly converging downslope into several wider and flat-bottomed channels without a marked headwall. This channel system is diverted around seafloor irregularities (cones and blocks) and ends gradually around 30-60 km from the shelf break.

\subsubsection{SW Desertas}

This landslide is inferred from a $\sim 10 \mathrm{~km}$ wide concave incision of the shelf break, roughly mimicked by the arcuate coastline of the adjacent Deserta Grande (annotation 5 in Figure 5 and Table 1). Downslope of the headwall scar, there is a mid-slope bench at $-400 \mathrm{~m}$, where three U-shaped, 1-2 km-wide channels originate. These channels run perpendicular to the slope (WSW-ENE) for $\sim 19 \mathrm{~km}$ where they merge into a larger channel oriented roughly N-S coming from SE Madeira. 
153

154

155

156

157

158

159

160 161 shape.

162

163

164

165

166

167

168

169

170

171

172

173

174

\subsubsection{SE Desertas}

This landslide is also inferred from the concave morphology of the shelf break and by the arcuate coastline of Bugio (annotation 6 in Figure 5 and Table 1). The headwall scar is $\sim 9 \mathrm{~km}$ wide, adjacent to a wide chute area incised by small gullies. At around $-2000 \mathrm{~m}$ and $6 \mathrm{~km}$ from the shelf edge, the gullies stem into a series of small parallel channels less than $1 \mathrm{~km}$ wide, which incise the seafloor up to $20 \mathrm{~km}$ offshore. At the end of the channels there are some scours perpendicular to the channels' direction, followed by a large wave field (see sections 4.3 and 4.4 and Figure 7). The entire system (channel, scours and wave fields) exhibits a somewhat lobate

\subsubsection{S S Porto Santo}

This landslide is also inferred by the concave shelf break with a $\sim 10 \mathrm{~km}$ wide headwall scar, backed by a coastline mimicking the arcuate shelf edge (annotation 7 in Figure 5 and Table 1). Below the shelf break, there is a wide chute area of 5-6 km in length stemming into a system of channels at its base. The westernmost channel discharges on a larger channel that collects sediments from other smaller channels dissecting the NE slopes of Desertas. This main channel marks the SW border of a lobate feature containing the landslide chute, channels, scours, and wave fields (Figures 5 and 7).

\subsubsection{N Porto Santo}

This landslide has a very arcuate headwall scar, $\sim 9 \mathrm{~km}$ wide that gives away downslope to a series of divergent gullies and channels (annotation 8 in Figure 5 and Table 1). The areas between the channels are extremely scoured whilst the channels are filled with rhythmic waves (see sections 4.3 and 4.4 and Figure 7). 


\subsection{Gullies and Channels}

The submarine flanks of Madeira, Desertas, and Porto Santo are extensively incised by numerous gullies and channels (Figure 5). These can be easily distinguished in the backscatter mosaic, showing linear features with high backscatter values (corresponding to coarser sediments) relative to the surrounding environment (Figure 4). The shelf edge around the islands often exhibits small headscars that stem into one or more gullies, suggesting continuous headwall erosion and transport downslope. The gullies are located on the steepest upper submarine flanks of the islands (gradients $>15^{\circ}$ ); they are $\mathrm{V}$-shaped in cross-section and can be up to $5-10 \mathrm{~km}$ in length and a few hundred metres wide. They can either be parallel or dendritic, but the later dominates, normally converging into U-shaped channels. The channels develop normally at gradients lower than $15^{\circ}$, commonly with parallel to dendritic pattern. The dendritic channels often converge downslope into a larger main channel, whilst the parallel ones remain with that configuration or in some cases diverge, forming fan-shaped systems. The smaller and upper channels are $\sim 500 \mathrm{~m}$-wide, but the lower and wider ones can reach $5 \mathrm{~km}$ in width and extend up to $60-70 \mathrm{~km}$ from the shelf break (as in NW Madeira). These channel systems are well developed on the northern and southern submarine flanks of Madeira, and in the area between Desertas and Porto Santo. They are less developed on the W and E slopes of Desertas and the NE and E of Porto Santo. They are absent on the NNW Madeira and in the NW, W, and SW slopes of Porto Santo. In the NW and SE of Madeira, the channels are deflected by large irregularities on the seafloor. SW of Madeira, the channel system probably extends much further than we can disclose $(\sim 35 \mathrm{~km})$, but the lack of multibeam bathymetry in this area prevented mapping the entire system. 


\subsection{Sediment wave fields}

Sediment wave fields are found East of Desertas, SE and NE of Porto Santo and, NNW of Madeira (Figure 7). Their wave length generally increases with increasing water depths (Figure 8 and Table 2).

\subsubsection{East of Desertas}

At Desertas, sediment wave fields are present on their eastern slopes below $-3000 \mathrm{~m}$ and where gradients are $<5^{\circ}$ (Figures 7 and 8 ). At this depth, the channels that incise the slope of Desertas gradually disappear and give way to scours. Thus, the scours constitute a gradual transition to the wave fields, making them difficult to separate in some places. Immediately below the transitional area (at -3000 to $-3800 \mathrm{~m}$ and gradients $2.9^{\circ}-3.7^{\circ}$ ), the bedforms exhibit wave lengths of 1350-2000 m and wave heights of 150-350 m. Below -3800 m and, down to $4300 \mathrm{~m}$, seafloor gradients decrease from $2^{\circ}$ to $0.6^{\circ}$ and the bedforms become widely spaced (1900-4200 m) and taller(500-1400 m). Generally, these bedforms show sinuous and often undulating crestlines in plan-view and are upslope asymmetrical in cross-section (according to the classification of Symons et al., 2016). The stoss sides slope shoreward, and are normally less steep and shorter than the lee sides that slope seaward. However, examples of downslope asymmetrical cross-sections are also found showing stoss sides sloping seaward. There are mainly two fields of bedforms, one in front of the eastern landslide headwall scar(bfl in Figure 7) and another (bf2 in Figure 7) that extends downslope at the end of a series of parallel channels (Figure 5). 


\subsubsection{SE Porto Santo}

SE of Porto Santo, the wave fields occur on top of a volcaniclastic bulge with lobateshape (bf3 in Figures 7 and 8). The bedforms also occur downslope of scours, showing a transition from well-developed scours to more rhythmic bedforms. The bedforms develop between $-3400 \mathrm{~m}$ and $-4000 \mathrm{~m}$ at seafloor gradients $<2.4^{\circ}$. Generally, these bedforms show less sinuous crestlines in plan-view and are downslope asymmetrical in cross-section.

\subsubsection{NE Porto Santo}

NE of Porto Santo bedforms develop in two settings (Figures 7 and 8 ). Some bedforms can be found inside channels (indicated by arrows and bf4 in Figure 7) and others (bf5 in Figure 7) on top of a volcaniclastic bulge with a lobate-shape. In both cases there are no scours upslope of the bedforms.

On top of the bulge, bedforms occur at $-3300 \mathrm{~m}$ to $-3600 \mathrm{~m}$, on seafloor gradients of $1.4^{\circ}$, with wave lengths of $1300-2400 \mathrm{~m}$ and wave heights of $4-16 \mathrm{~m}$. They show somewhat crescent upslope crestlines in plan-view and are downslope asymmetrical in cross-section.

Inside the channels, bedforms occur at $-3000 \mathrm{~m}$ to $-3500 \mathrm{~m}$, in seafloor gradients of $1.2^{\circ}$ $1.9^{\circ}$, with wave lengths of $600-2000 \mathrm{~m}$ and wave heights of 2-17 $\mathrm{m}$. They show crescent downslope crests in plan-view and have both downslope and upslope asymmetry in crosssection. On the shallower sections of the channels, bedforms probably also exist but the resolution of the bathymetry does not allow the identification of these features.

\subsubsection{NNW Madeira}

Here the bedforms develop on top of a lobate body, stemming from an arcuate scar (bf 6 in Figure 7) at the shelf edge. The bedforms occur between $-3400 \mathrm{~m}$ to $-3700 \mathrm{~m}$ on a seafloor 
with gradients between $0.8-1.9^{\circ}$. Upslope, they are bounded by a series of sinuous scours that can extend up to $-3000 \mathrm{~m}$. The bedforms show an almost linear shape in plan view and are upslope asymmetrical in cross-section.

\subsection{Scours}

The term scour is used here to denote erosional bedforms, often characterized by enclosed depressions (Wynn et al., 2002; Symons et al., 2016). They were identified in the bathymetry as headwall scars mostly transverse to the main slope, being generally deeper downslope of the headwall. Being abundant on the lower slopes of Madeira Archipelago (Figure 7), these features were found in four different settings: (1) between the channel systems and the wave fields (e.g., E of Desertas and SE of Porto Santo); (2) at the end of the gully/channel systems but without offshore wave fields (e.g., N, NW and E of Porto Santo and around the southern tip of Desertas), (3) where no channel system exists (e.g., NNW and SSW of Madeira, the latter displaying the largest scours); and; (4) on ridges between the channels (e.g., S and NE of Madeira).

These structures display mostly linear to sinuous shapes in plan-view. The sinuous ones are commonly rectangular or U-shaped in plan-view and seem to be formed by coalescing individual scours. The coalescing scours feature headwalls up to $10-30 \mathrm{~km}$ in width, $20 \mathrm{~km}$ in length and $200 \mathrm{~m}$ deep (e.g., SW of Madeira). Individual scours can be less than $1 \mathrm{~km}$ in width and length, and 10-20 m deep. Smaller scours were not mapped because they fall beyond the resolution of bathymetry. All scours occur within the same depth range (-3000 to $-4300 \mathrm{~m})$ and seafloor gradients $\left(0.5^{\circ}-3^{\circ}\right)$ as the wave fields. 


\section{Discussion}

\subsection{Large landslides}

It has been proposed that the occurrence of large landslides (involving volumes in excess of $1 \mathrm{~km}^{3}$ or areas over a few hundreds of $\mathrm{km}^{2}$, Siebert, 1984; Paris et al., 2018) is controlled by edifice elevation and topography of individual islands (Mitchell, 2003). Here we explore our observations of large landslides in Madeira Archipelago and set these in the context of other volcanic islands.

Eight large landslides were identified and most of them exhibit: (i) well-defined amphitheatres at their source regions; (ii) well defined chute areas of up to $10 \mathrm{~km}$ in length and 2 $\mathrm{km}$ in height; and (iii) debris avalanche fields with somewhat lobate shapes, albeit being significantly incised by channel systems. Some of these slide deposits still exhibit hummocky morphologies with mega blocks up to $2 \mathrm{~km}$ wide (NW and SE Madeira). Additionally, with the exception of the landslides inferred SE of Madeira and N of Porto Santo, all sites exhibit concave coastlines mimicking the arcuate shelf break scars. It must be noted, however, that the SE Madeira landslide probably also created an arcuate coastline - corresponding to the "Funchal amphitheatre" - but the area has subsequently been covered by post-collapse volcanism (Brum da Silveira et al., 2010a). The western lateral ramp of this landslide probably corresponds to the erosional unconformity observed at Cabo Girão between the Middle and the Upper Volcanic Complexes and thus it must pre-date the Lombos Unit of the Upper Volcanic Complex ( 1.8 Ma, Brum da Silveira et al., 2010a). Nevertheless, the size and extent of the debris avalanche deposits (larger than the NW landslide) suggest a greater volume than the one implied by Brum da Silveira et al. (2010a). Thus, we do not exclude the possibility that this avalanche debris corresponds to an earlier and larger event than the "Funchal landslide". Otherwise the Funchal 
284 ridge ( $<3 \mathrm{Ma}$, according to Geldmacher et al., 2006) would have been buried by the debris 285 avalanche flow.

287 affected the subaerial and submarine portions of the volcanic edifices. Subsequently, the incision of the island flanks by waves during Quaternary glacio-eustatic sea level-oscillations produced the observed shelves ( $>1 \mathrm{~km}$ wide). In the Azores, such wide shelves were produced over several hundreds of thousands of years (Quartau et al., 2010; Quartau et al., 2012; Quartau et al., 2014; Quartau et al., 2015b; 2016). Therefore, we suspect that all these major landslides are also at least several hundreds of thousands of years, since they show at least one of the following features: (1) well-developed channel systems in front of their chutes, incising the debris avalanche deposits; (2) relatively wide-shelves $(>1 \mathrm{~km})$ in front of the arcuate coastlines, and (3) filling by post-collapse volcanism, dating at least several hundreds of thousands of years (Brum da Silveira et al., 2010a; 2010b). et al., 2003). They are also similar to the landslides in Hawaii with the exception of the three largest ones (North Kauai, Nuuanu at Oahu, and Wailau at Molokai), which are three to six times larger than the SE Madeira landslide (Table 1 at Moore et al., 1989). Landslides at Porto Santo and Desertas are, however, smaller than the ones at Madeira. Thus, this study also suggests that there is a clear relationship between landslide dimension and island sizes/topography, as it happens in other archipelagos. Mitchell (2003) also suggested that landslides are more common in edifices taller than $2500 \mathrm{~m}$. Landslides with dimensions similar to the smaller ones at Hawaii and Canaries, however, also occur at Porto Santo and Desertas, which are islands that clearly 
never reached such heights. Further studies are therefore needed to understand exactly which conditions favour these catastrophic events at Madeira Archipelago and on other island settings.

\subsection{Gullies and channels}

The submarine network of gullies and channels is very well developed $\mathrm{N}$ and $\mathrm{S}$ of Madeira and between Desertas and Porto Santo where channels from both islands converge into a larger main channel. The parallel gullies (V-shaped) in the upper slope converge downslope into wider and flat-bottomed channelized features (U-shaped). In turn, these structures also tend to converge into one or more larger channels, with transition from gullies to channels occurring at gradients smaller than $15^{\circ}$. The increase in width downslope could be the result of lateral erosion predominating over vertical incision. This and the decrease of gradients could promote deceleration of the flows and consequent sediment infilling of the seafloor creating the U-shaped drainage system. The pathways of these features are strongly influenced by the presence of rocky outcrops. Consequently, this tributary system is absent where protruding rocky outcrops and bulge areas are abundant such as to the W of Porto Santo and NNW of Madeira. It is also poorly developed to the NE of Madeira. To the NW and SE of Madeira, the channels, albeit being welldeveloped, are diverted around obstacles such as the volcanic cones and collapsed blocks.

According to Krastel et al. (2001), submarine drainage in Gran Canaria and Tenerife (Canaries) was initiated by flash floods that crossed the island shelf as hyperpycnal flows. When these flows reached the steep upper slopes of the islands, they accelerated and carved protogullies aligned with the subaerial drainage. Other studies provided similar interpretations for the formation of submarine drainage at Tenerife, El Hierro (Mitchell et al., 2003), La Gomera (Llanes et al., 2009) and Réunion Islands (Mazuel et al., 2016). When volcanic activity wanes, abrasion and widening of the insular shelf prevents the direct stream discharge on the insular 
slope and the development of the submarine drainage diminishes (Mitchell et al., 2003).

However, the submarine drainage once initiated is probably continued by exceptional erosive sediment flows coming from onshore, and reaching the upper slopes of the islands and/or by failures of the gullies' walls (where gradients reach $>15^{\circ}$ ). In either case, downslope eroding flows such as turbidites, are probably responsible for the development of the submarine drainage.

$$
\text { The three main factors controlling sediment supply and transport offshore volcanic }
$$
islands are, in decreasing importance, volcanic activity, climate and sea-level changes (Krastel et al., 2001). Turbidites are more likely formed during flank collapses and syn-eruptive mass flows (e.g., pyroclastic flows, lahars) (Manville et al., 2009). Hence, sedimentation rates in the slope apron are likely to be highest during phases of high volcanic activity and decrease during noneruptive phases (Carey and Schneider, 2011). When volcanic activity wanes, subaerial erosion increases and gullies evolve into streams bringing terrigenous sediments to the shelf (Saint-Ange et al., 2013). Steeper slopes and high precipitation rates result in stronger erosion that generates hyperpycnal flows, which are capable of transporting riverine sediments across the shelf onto the edge (Mazuel et al., 2016). An additional important source of material is the reworking of unconsolidated volcaniclastic material previously deposited in the marine environment, termed 'secondary volcaniclastic turbidites' (Carey and Schneider, 2011). Storm waves are able to transport large amounts of nearshore sediments into the shelf edge and upper slopes of the islands (Tsutsui et al., 1987). The initiation of submarine gravity flows by storm waves is recognised on continental margins where narrow shelves exist and canyon heads incise most of the shelf (e.g. at La Jolla and Monterey canyons, Piper and Normark, 2009). Sediments deposited progressively nearby the canyon heads or the outer shelf during floods can become unstable and fail when a loading threshold is reached (Mazuel et al., 2016). Shelf storage also controls the flux 
353 of turbidites to the deep sea: in principle, sea-level highstands favour the accumulation of

354 sediments on the shelf, whereas sea-level lowstands are expected to result in important

355 sedimentary remobilization and transport towards the deeper parts of aprons (Carey and

356 Schneider, 2011). According to cores in Figures 8 and 10 of Hunt et al. (2013), there are 9

357 volcaniclastic turbidites originated at Madeira and/or Desertas between $34 \mathrm{ka}$ and $106 \mathrm{ka}$, which

358 gives a recurrence time of 8 kyrs for large turbidite emplacement. Given the age uncertainties

359 and that turbidites were emplaced during interglacial (MIS 5) and glacial (MIS 3 and 4) periods

360 (when sea-level rose and fell), a correlation between higher productivity of turbidites related to

361 glacio-isostatic changes is impossible to establish.

The islands composing Madeira Archipelago are markedly different concerning their age,

363 subaerial height and morphology, and precipitation rates. Madeira is a young and tall island

364 (almost $2000 \mathrm{~m}$ ), with extremely incised and high gradient streams, precipitation values up to

$3653000 \mathrm{~mm} /$ year and a known history of flash-floods. These characteristics contrast greatly with

366 the low islands of Porto Santo and Desertas, which feature poorly developed streams, low

367 precipitation rates and did not experience recent volcanism. Unfortunately additional studies

368 presenting high resolution submarine data as Madeira Archipelago and Réunion Island do not

369 exist, precluding a better discussion on the factors controlling the size of the submarine tributary

370 systems. Nevertheless, some inferences can be drawn based on the diverse islands at Madeira

371 Archipelago. The size of the respective submarine tributary system is apparently controlled by

372 the relatively age of the islands' subaerial topography, and their precipitation rates. Turbidites

373 derived directly from volcanic eruptions are unlikely in Madeira Island because volcanism is

374 dominantly effusive (Geldmacher et al., 2000; Brum da Silveira et al., 2010a). Thus, during

375 flash-floods in Madeira, sediments probably reach the edge of the shelf as hyperpycnal flows, 
376 feeding the gullies and promoting their development. Unfortunately, with exception of the 2010

377 flash-flood episode, there are no records of sediment concentrations and discharge from streams

378 at Madeira Archipelago. The same process is inferred to explain the well-developed

379 volcaniclastic deep-sea fans around Réunion Island (Sisavath et al., 2012; Babonneau et al.,

380 2013; Mazuel et al., 2016). These are larger (100-300 km long) than those of Madeira Island

381 because Réunion is taller $(\sim 3000 \mathrm{~m})$, subjected to heavier rainfall ( $>5000 \mathrm{~mm} / \mathrm{year})$, and exposed

382 to tropical cyclones. On the older Porto Santo and Desertas islands, which do not exhibit well-

383 developed onshore drainage networks, storm-induced offshore currents are likely the only

384 process delivering sediments to the upper slopes. Such mechanism possibly explains the triggering of small-scale mass-wasting at the shelf edge at Oahu (Tsutsui et al., 1987) and in the 386 Azores (Quartau et al., 2012; Meireles et al., 2013). Data acquisition of shelf currents and river 387 discharge is fundamental to support these inferences and therefore further research is needed to 388 fully understand a possible relationship between stream sediment discharge (and consequently 389 the maturity of drainage networks) and shelf sediment dynamics.

The submarine drainage in Madeira Archipelago is also present on top of debris flow

391 fields, being more developed where these fields are larger. This is because collapse scars commonly act as traps for subsequent sedimentation, leading to enhanced sedimentation rates and increasing the risk of further landslides at the shelf edge (Masson et al., 2006).

\subsection{Sediment wave fields} NNW of Madeira (Figure 7). They can be classified into three main types according to their setting: (1) wave fields associated to depositional lobes as in the cases of the major landslides of NNW Madeira, E of Desertas, and SE and NE of Porto Santo; (2) wave fields downstream of the 
gullies and channels system E of Desertas and; (3) wave fields inside channels, $\mathrm{N}$ of Porto Santo (indicated by arrows in Figure 7). These bedforms generally have wave heights over $9 \mathrm{~m}$ (and up to $94 \mathrm{~m}$ ) and wave lengths exceeding $600 \mathrm{~m}$ (and up to $4000 \mathrm{~m}$ ).

Undulated bedforms are normally generated by bottom currents, either from downslopeflowing turbidity currents or from alongslope-flowing currents (Wynn and Stow, 2002). They can also be formed by soft sediment deformation (e.g. extensional faults or creep folds, Wynn and Stow, 2002). Most of these bedforms occur seaward of the large landslides and are could be compressional features of their debris avalanche deposits, forming poorly-defined depositional distal lobes. In order to distinguish the processes involved in bedform formation, high-resolution seismic reflection and bathymetric data as well as sediment sampling would be required (Wynn and Stow, 2002). However, only high-resolution bathymetry is available for this study, which precludes an interpretation of the wave-forming process. Nevertheless, bedforms with these characteristics (over $6 \mathrm{~m}$ height and $300 \mathrm{~m}$ wave lengths) are considered large sediment waves, typically located in relatively unconfined settings and composed of fine-grained sediment (Symons et al., 2016). In Madeira Archipelago these features share common characteristics; (1) they occur within the same depth range (3000-4300m); (2) their crest-lines are always roughly perpendicular to the maximum slope direction; (3) most of them are located where the channel systems end; and, (4) they are located where the seafloor gradients significantly decrease to $0.5^{\circ}$ $3^{\text {o. }}$ Thus, the wave fields were probably generated at the base of the island flanks by deeper unconfined turbidity currents. In addition, the sinuous morphologies are normally found on bedforms generated by flows rather than slope failures (Wynn and Stow, 2002; Symons et al., 2016). These flows were probably initially constrained within the gullies and channels but rapidly became unconfined downslope where the drainage systems open, spreading out over 
422 wide areas. Where channel systems are well developed, the flows are confined, and sediment

423 waves do not form (e.g., $\mathrm{N}$ and $\mathrm{S}$ of Madeira). Wave fields with similar characteristics (wave

424 height and lengths) have been found in other volcanic environments such as the Aeolian

425 (Casalbore et al., 2014), Canaries (Wynn et al., 2000a), Cape Verde (Masson et al., 2008),

426 Selvagens (Wynn et al., 2000b), and Reunion islands (Mazuel et al., 2016), and were mostly

427 interpreted to have a similar origin. Bedforms with such wave heights and wave lengths are

428 believed to be the result of cyclic steps formed by turbidity currents. Deposition occurs

429 predominantly on the upslope flank and erosion on the downslope flank, resulting in the up-

430 current migration of the bedform crests (Cartigny et al., 2011). The reduction of slope gradients

431 at -3000 to $-4300 \mathrm{~m}$ would probably force the flow to pass the hydraulic jump, during which its

432 velocity would be reduced significantly and deposition would occur, favouring the development

433 of these bedforms. Other wave fields found in the South Sandwich (Leat et al., 2010) and

434 Bismarck volcanic arcs (Hoffmann et al., 2008; Hoffmann et al., 2011) were interpreted as

435 formed by both mechanisms (turbidity currents and seafloor deformation). Thus, our preference

436 for the turbidite hypothesis is not strongly supported at this stage without further data.

\subsection{Scours}

All these features occur within the same depth range (3000-4300m) and seafloor

439 gradients $\left(0.5^{\circ}-3^{\circ}\right)$. There are however some differences in their setting. East of Desertas they are

440 located immediately downslope of the channel systems and upslope of the sediment wave fields.

441 Around Porto Santo they normally lay downslope of the channel systems. Given that the

442 sediment wave fields are hypothesized to be formed by hydraulic jumps driven by significant

443 reduction of seafloor gradients, it is likely that the scours have a similar origin. Unconfined

444 turbidity currents suffer the first significant hydraulic jump due to the reduction of slope 
gradients, promoting erosion of the seafloor sediment cover (Mutti and Normark, 1987). Scours were also found $\mathrm{W}, \mathrm{SW}$, and $\mathrm{S}$ of Madeira where no channels exist or in ridges between channels. These are normally the largest scours, suggesting that in places where the turbidity currents have no constrain, they have a higher erosive power. Similar features have been found in other volcanic environments such as the Bismarck volcanic arc (Hoffmann et al., 2011), South Sandwich volcanic arc (Leat et al., 2010) and Reunion islands (Saint-Ange et al., 2013) where they are also attributed to the action of turbidity currents.

\section{Conclusions}

Once built, the submarine flanks of volcanic ocean islands are shaped by a variety of physical processes that leads to the establishment of large submarine tributary systems that extend to the abyssal plains. These gravitational, erosional, and depositional processes, however, are still poorly understood, and so are many of the morphologies associated to such tributary systems. In particular, it is still not clear how distinct morpho-climatic conditions of individual volcanic islands influence erosion and deposition in their submarine. To address this problem, we performed a comprehensive overlook at the gravitational, erosional, and depositional processes affecting the submarine flanks of an entire archipelago, using a high-resolution dataset covering from the nearshore to the abyssal plains. This study is therefore one of the few to offer a comprehensive source-to-sink approach in the study of submarine tributary systems, linking different island subaerial morphologies and physiographic conditions with near-shore shelf, slope, and far-field abyssal features. Additionally to being the first morphological description of the seafloor around Madeira, Porto Santo, and Desertas Islands, this study allowed a comparison 
467 with other archipelagos, showing how distinct island characteristics promote diverse submarine 468 evolutions. by huge subaerial and submarine flank collapses, with dimensions comparable to some of the large landslides in Hawaii or the Canary Islands. As proposed to other archipelagos, a clear relationship between island size and landslide areas was shown to exist, but an obvious link between island height and landslide areas proved more elusive. The integration of the subaerial and submarine data also allowed a discussion of their ages, pointing at least to a few kyrs. revealed how sediments are dislodged and transported downslope to form volcaniclastic aprons. At Madeira Island, sediments reach the shelf edge by hyperpycnal flows to induce mass-wasting, showing the importance of such process on highly-dissected edifices subjected to high riverine discharge, as it also happens in Réunion Island. In Desertas and Porto Santo, sediments are more likely transported offshore during storms. Some of these tributary systems develop on top of the large landslide scars and paths reinforcing that these slides are older features. slopes of the islands, the sudden gradient decrease promotes hydraulic jumps that first, causes the

484 formation of scours, and second, of wave fields. Sediment waves appear mostly in the depositional lobes of the landslides and seaward of poorly-developed channel systems. Where channel systems are well developed and/or protruding rocky outcrops exist, sediment wave fields are absent. The largest scours are only present in areas without channel systems, showing that in these places the hydraulic jump produced by unconstrained turbidite currents is enhanced. Our data strongly supports the general conclusion that high and rainy islands tend to form well- 
490 developed and confined volcaniclastic turbidite systems, whilst on low and dry islands

491 unconfined and smaller turbidite systems predominate, favouring the development of scours and

492 sediment wave fields.

\section{Acknowledgments}

This work is a contribution of SEDMAR program funded by IH. EMEPC and IFREMER are acknowledged for sharing datasets (respectively multibeam bathymetry and multichannel seismic reflection profiles). RQ and RR acknowledge their IF/00635/2015 and IF/01641/2015 contracts funded by Fundação para a Ciência e a Tecnologia. Duarte Costa at Direção de Serviços de Informação Geográfica e Cadastro do Governo Regional da Madeira is acknowledged for providing the digital altimetry used in this study. Neil Mitchell, an anonymous reviewer and the Editor Tamsin Mather are gratefully acknowledged for suggestions that significantly improved this manuscript.

\section{References}

Acosta, J., Uchupi, E., Muñoz, A., Herranz, P., Palomo, C., Ballesteros, M., 2003. Geologic evolution of the Canarian Islands of Lanzarote, Fuerteventura, Gran Canaria and La Gomera and comparison of landslides at these islands with those at Tenerife, La Palma and El Hierro. Mar. Geophys. Res. 24, 1-40.

Babonneau, N., Delacourt, C., Cancouët, R., Sisavath, E., Bachèlery, P., Mazuel, A., Jorry, S.J., Deschamps, A., Ammann, J., Villeneuve, N., 2013. Direct sediment transfer from land to deepsea: Insights into shallow multibeam bathymetry at La Réunion Island. Mar. Geol. 346, 47-57.

Baioni, D., 2011. Human activity and damaging landslides and floods on Madeira Island. Nat. Hazards Earth Syst. Sci. 11, 3035-3046.

Brum da Silveira, A., Madeira, J., Ramalho, R., Fonseca, P., Prada, S., 2010a. Notícia Explicativa da Carta Geológica da ilha da Madeira na escala 1:50.000, Folhas A e B. Secretaria 
Regional do Ambiente e Recursos Naturais e Universidade da Madeira. 47 p. ISBN: 978-97298405-2-4.

Brum da Silveira, A., Madeira, J., Ramalho, R., Fonseca, P., Rodrigues, C., Prada, S., $2010 b$. Carta Geológica da ilha da Madeira na escala 1:50.000, Folhas A e B. Secretaria Regional do Ambiente e Recursos Naturais e Universidade da Madeira. 2 sheets at the 1:50,000 scale. ISBN: 978-972-98405-1-7.

Calder, B.R., Mayer, L.A., 2003. Automatic processing of high-rate, high-density multibeam echosounder data. Geochem. Geophys. Geosyst. 4.

Carey, S.N., Schneider, J.-L., 2011. Chapter 7 - Volcaniclastic Processes and Deposits in the Deep-Sea, in: Heiko, H., Thierry, M. (Eds.), Developments in Sedimentology. Elsevier, Amsterdam, pp. 457-515.

Cartigny, M.J.B., Postma, G., van den Berg, J.H., Mastbergen, D.R., 2011. A comparative study of sediment waves and cyclic steps based on geometries, internal structures and numerical modeling. Mar. Geol. 280, 40-56.

Casalbore, D., Romagnoli, C., Bosman, A., Chiocci, F.L., 2014. Large-scale seafloor waveforms on the flanks of insular volcanoes (Aeolian Archipelago, Italy), with inferences about their origin. Mar. Geol. 355, 318-329.

Cornen, G., Girardeau, J., Agrinier, P., Grasset, O., Hinschberger, F., Loyen, H., Malod, J., Matias, L., Monteiro, J., Pinheiro, L., Quillacq, B.d., Ribeiro, A., Thinon, I., 2003. Campagne Tore-Madère - Premiers résultats. Rapport non publié - Univ-Nantes, p. 113.

Ferreira, J.C., Cunha, L.V., 1984. Prediction of soil erosion in the island of Porto Santo (Portugal). Memória LNEC 622, Lisboa.

Geldmacher, J., Hoernle, K., Klügel, A., van den Bogaard, P., Duggen, S., 2006. A geochemical transect across a heterogeneous mantle upwelling: Implications for the evolution of the Madeira hotspot in space and time. Lithos 90, 131-144.

Geldmacher, J., van den Bogaard, P., Hoernle, K., Schmincke, H.-U., 2000. The 40Ar/39Ar age dating of the Madeira Archipelago and hotspot track (eastern North Atlantic). Geochem. Geophys. Geosyst. 1, 1-26.

Hoffmann, G., Silver, E., Day, S., Morgan, E., Driscoll, N., Orange, D., 2008. Sediment waves in the Bismarck Volcanic Arc, Papua New Guinea. Geological Society of America Special Papers 436, 91-126. 
Hoffmann, G., Silver, E., Day, S.J., Driscoll, N., Orange, D., 2011. Deformation versus deposition of sediment waves in the Bismarck Sea, Papua New Guinea, in: Shipp, R.C., Weimer, P., Posamentier, H.W. (Eds.), Mass-Transport Deposits in Deepwater Settings. SEPM Society for Sedimentary Geology, Tulsa, pp. 455-474.

Hunt, J.E., Talling, P.J., Clare, M.A., Jarvis, I., Wynn, R.B., 2014. Long-term (17 Ma) turbidite record of the timing and frequency of large flank collapses of the Canary Islands. Geochem. Geophys. Geosyst. 15, 3322-3345.

Hunt, J.E., Wynn, R.B., Talling, P.J., Masson, D.G., 2013. Frequency and timing of landslidetriggered turbidity currents within the Agadir Basin, offshore NW Africa: Are there associations with climate change, sea level change and slope sedimentation rates? Mar. Geol. 346, 274-291.

Klügel, A., Klein, F., 2006. Complex magma storage and ascent at embryonic submarine volcanoes from the Madeira Archipelago. Geology 34, 337-340.

Klügel, A., Schwarz, S., van den Bogaard, P., Hoernle, K., Wohlgemuth-Ueberwasser, C., Köster, J., 2009. Structure and evolution of the volcanic rift zone at Ponta de São Lourenço, eastern Madeira. Bull. Volc. 71, 671-685.

Krastel, S., Schmincke, H.-U., Jacobs, C.L., 2001. Formation of submarine canyons on the flanks of the Canary Islands. Geo-Mar. Lett. 20, 160-167.

Leat, P.T., Tate, A.J., Tappin, D.R., Day, S.J., Owen, M.J., 2010. Growth and mass wasting of volcanic centers in the northern South Sandwich arc, South Atlantic, revealed by new multibeam mapping. Mar. Geol. 275, 110-126.

Lira, C., Lousada, M., Falcão, A.P., Gonçalves, A.B., Heleno, S., Matias, M., Pereira, M.J., Pina, P., Sousa, A.J., Oliveira, R., Almeida, A.B., 2013. The 20 February 2010 Madeira Island flashfloods: VHR satellite imagery processing in support of landslide inventory and sediment budget assessment. Nat. Hazards Earth Syst. Sci. 13, 709-719.

Llanes, P., Herrera, R., Gómez, M., Muñoz, A., Acosta, J., Uchupi, E., Smith, D., 2009. Geological evolution of the volcanic island La Gomera, Canary Islands, from analysis of its geomorphology. Mar. Geol. 264, 123-139.

Manville, V., Németh, K., Kano, K., 2009. Source to sink: A review of three decades of progress in the understanding of volcaniclastic processes, deposits, and hazards. Sed. Geol. 220, 136-161.

Masson, D.G., Le Bas, T.P., Grevemeyer, I., Weinrebe, W., 2008. Flank collapse and large-scale landsliding in the Cape Verde Islands, off West Africa. Geochem. Geophys. Geosyst. 9, doi:10.1029/2008GC001983. 
Masson, D.G., Watts, A.B., Gee, M.J.R., Urgeles, R., Mitchell, N.C., Le Bas, T.P., Canals, M., 2002. Slope failures on the flanks of the western Canary Islands. Earth-Sci. Rev. 57, 1-35.

Mata, J., Fonseca, P., Prada, S., Rodrigues, D., Martins, S., Ramalho, R., Madeira, J., Cachão, M., Marques da Silva, C., Matias, M.J., 2013. O arquipélago da Madeira, in: Dias, R., Araújo, A., Terrinha, P., Kullberg, J.C. (Eds.), Geologia de Portugal, Volume II - Geologia Mesocenozóica de Portugal. Escolar Editora, pp. 691-746.

Mazuel, A., Sisavath, E., Babonneau, N., Jorry, S.J., Bachèlery, P., Delacourt, C., 2016. Turbidity current activity along the flanks of a volcanic edifice: The Mafate volcaniclastic complex, La Réunion Island, Indian Ocean. Sed. Geol. 335, 34-50.

Meireles, R., Quartau, R., Ramalho, R.S., Rebelo, A.C., Madeira, J., Zanon, V., Ávila, S.P., 2013. Depositional processes on oceanic island shelves - evidence from storm-generated Neogene deposits from the mid-North Atlantic. Sedimentology 60, 1769-1785.

Mitchell, N.C., 2003. Susceptibility of mid-ocean ridge volcanic islands and seamounts to largescale landsliding. J. Geophys. Res. 108, 2397, B8.

Mitchell, N.C., Dade, W.B., Masson, D.G., 2003. Erosion of the submarine flanks of the Canary Islands. J. Geophys. Res. 108, 3-1 - 3-11.

Moore, J.G., Clague, D.A., Holcomb, R.T., Lipman, P.W., Normark, W.R., Torresan, M.E., 1989. Prodigious submarine landslides on the Hawaiian Ridge. J. Geophys. Res.: Solid Earth 94, 17465-17484.

Mutti, E., Normark, W.R., 1987. Comparing examples of modern and ancient turbidite systems: problems and concepts, in: Leggett, J.K., Zuffa, G.G. (Eds.), Marine clastic sedimentology: concepts and case studies. Graham and Trotman, London, pp. 1-38.

Paris, R., Ramalho, R.S., Madeira, J., Ávila, S., May, S.M., Rixhon, G., Engel, M., Brückner, H., Herzog, M., Schukraft, G., Perez-Torrado, F.J., Rodriguez-Gonzalez, A., Carracedo, J.C., Giachetti, T., 2018. Mega-tsunami conglomerates and flank collapses of ocean island volcanoes. Marine Geology 395, 168-187.

Piper, D.J.W., Normark, W.R., 2009. Processes That Initiate Turbidity Currents and Their Influence on Turbidites: A Marine Geology Perspective. J. Sediment. Res. 79, 347-362.

Prada, S.N., Silva, M.O., Cruz, J.V., 2005. Groundwater behaviour in Madeira, volcanic island (Portugal). Hydrogeol J 13, 800-812.

Quartau, R., Hipólito, A., Mitchell, N.C., Gaspar, J.L., Brandão, F., 2015a. Comment on "Construction and destruction of a volcanic island developed inside an oceanic rift: Graciosa 
Island, Terceira Rift, Azores" by Sibrant et al. (2014) and proposal of a new model for Graciosa geological evolution [J. Volcanol. Geotherm. Res. 284 (2014) 32-45]. J. Volcanol. Geotherm. Res. 303, 146-156.

Quartau, R., Hipólito, A., Romagnoli, C., Casalbore, D., Madeira, J., Tempera, F., Roque, C., Chiocci, F.L., 2014. The morphology of insular shelves as a key for understanding the geological evolution of volcanic islands: Insights from Terceira Island (Azores). Geochem. Geophys. Geosyst. 15, 1801-1826.

Quartau, R., Madeira, J., Mitchell, N.C., Tempera, F., Silva, P.F., Brandão, F., 2015b. The insular shelves of the Faial-Pico Ridge: a morphological record of its geologic evolution (Azores archipelago). Geochem. Geophys. Geosyst. 16, 1401-1420.

Quartau, R., Madeira, J., Mitchell, N.C., Tempera, F., Silva, P.F., Brandão, F., 2016. Reply to comment by Marques et al. on "The insular shelves of the Faial-Pico Ridge (Azores archipelago): A morphological record of its evolution”. Geochem. Geophys. Geosyst. 17, 633641.

Quartau, R., Mitchell, N.C., 2013. Comment on "Reconstructing the architectural evolution of volcanic islands from combined K/Ar, morphologic, tectonic, and magnetic data: The Faial Island example (Azores)" by Hildenbrand et al. (2012) [J. Volcanol. Geotherm. Res. 241-242 (2012) 39-48]. J. Volcanol. Geotherm. Res. 255, 124-126.

Quartau, R., Tempera, F., Mitchell, N.C., Pinheiro, L.M., Duarte, H., Brito, P.O., Bates, R., Monteiro, J.H., 2012. Morphology of the Faial Island shelf (Azores): The interplay between volcanic, erosional, depositional, tectonic and mass-wasting processes. Geochem. Geophys. Geosyst., 13, Q04012, doi:10.1029/2011GC003987.

Quartau, R., Trenhaile, A.S., Mitchell, N.C., Tempera, F., 2010. Development of volcanic insular shelves: Insights from observations and modelling of Faial Island in the Azores Archipelago. Mar. Geol. 275, 66-83.

Ramalho, R.S., Brum da Silveira, A., Fonseca, P., Madeira, J., Cosca, M., Cachão, M., Fonseca, M., Prada, S., 2015. The emergence of volcanic oceanic islands on a slow-moving plate: the example of Madeira Island, NE Atlantic. Geochem. Geophys. Geosyst. 16, 522-537.

Saint-Ange, F., Bachèlery, P., Babonneau, N., Michon, L., Jorry, S.J., 2013. Volcaniclastic sedimentation on the submarine slopes of a basaltic hotspot volcano: Piton de la Fournaise volcano (La Réunion Island, Indian Ocean). Mar. Geol. 337, 35-52.

Schmidt, R., Schmincke, H.-U., 2002. From seamount to oceanic island, Porto Santo, central East-Atlantic. Int. J. Earth Sci. (Geol. Rundsch) 91, 594-614. 
Schmincke, H.-U., Sumita, M., 1998. Volcanic evolution of Gran Canaria reconstruction from apron sediments: synthesis of VICAP project drilling, in: Weaver, P.P.E., Schmincke, H.-U., Firth, J.V., Duffield, W. (Eds.), Proc. Ocean Drill. Prog. Sci. Res. 157, pp. 443-469.

Schwarz, S., Klügel, A., van den Bogaard, P., Geldmacher, J., 2005. Internal structure and evolution of a volcanic rift system in the eastern North Atlantic: the Desertas rift zone, Madeira archipelago. J. Volcanol. Geotherm. Res. 141, 123-155.

Siebert, L., 1984. Large volcanic debris avalanches: Characteristics of source areas, deposits, and associated eruptions. J. Volcanol. Geotherm. Res. 22, 163-197.

Sisavath, E., Babonneau, N., Saint-Ange, F., BachÃ"lery, P., Jorry, S.J., Deplus, C., De Voogd, B.a., Savoye, B., 2011. Morphology and sedimentary architecture of a modern volcaniclastic turbidite system: The Cilaos fan, offshore La Réunion Island. Mar. Geol. 288, 1-17.

Sisavath, E., Mazuel, A., Jorry, S.J., Babonneau, N., Bachèlery, P., de Voogd, B., Salpin, M., Emmanuel, L., Beaufort, L., Toucanne, S., 2012. Processes controlling a volcaniclastic turbiditic system during the last climatic cycle: Example of the Cilaos deep-sea fan, offshore La Réunion Island. Sedimentary Geology 281, 180-193.

Symons, W.O., Sumner, E.J., Talling, P.J., Cartigny, M.J.B., Clare, M.A., 2016. Large-scale sediment waves and scours on the modern seafloor and their implications for the prevalence of supercritical flows. Mar. Geol. 371, 130-148.

Tsutsui, B., Campbell, J.F., Coulbourn, W.T., 1987. Storm-generated, episodic sediment movements off Kahe Point, Oahu, Hawaii. Mar. Geol. 76, 281-299.

Wynn, R.B., Kenyon, N.H., Masson, D.G., Stow, D.A.V., Weaver, P.P.E., 2002. Characterization and Recognition of Deep-Water Channel-Lobe Transition Zones. AAPG Bull. $86,1441-1462$.

Wynn, R.B., Masson, D.G., Stow, D.A.V., Weaver, P.P.E., 2000a. Turbidity current sediment waves on the submarine slopes of the western Canary Islands. Mar. Geol. 163, 185-198.

Wynn, R.B., Stow, D.A.V., 2002. Classification and characterization of deep-water sediment waves. Mar. Geol. 192, 7-22.

Wynn, R.B., Weaver, P.P.E., Ercilla, G., Stow, D.A.V., Masson, D.G., 2000b. Sedimentary processes in the Selvage sediment-wave field, NE Atlantic: new insights into the information of sediment waves by turbidity currents. Sedimentology 47, 1181-1197. 
Figure 1. Upper-right inset shows the location of Madeira Archipelago (GF - Gloria Fault) and main panel shows the sources of the different bathymetric datasets. Black areas represent the continental and island landmasses. Coloured areas represent the bathymetric sources: yellow, data from coastal management projects; light-blue, from SEDMAR; dark blue, from EMEPC; and orange, from EMODnet projects. This map and the following have UTM $28 \mathrm{~N}$ coordinate system.

Figure 2. Shaded relief images of the subaerial topography of the islands of Madeira (1), Porto Santo (2) and Desertas (3). Data is from Direção de Serviços de Informação Geográfica e Cadastro do Governo Regional da Madeira.

Figure 3. Shaded relief image derived from the bathymetric compilation. Squares locate high resolution sub-sets of this bathymetric compilation.

Figure 4. Acoustic backscatter mosaic with low values in black and high values in white (-70 $\mathrm{dB}$ to $10 \mathrm{~dB})$.

Figure 5. Interpreted submarine topography: light blue lines represent the headwall scars of the landsides, black lines represent the gullies, dark blue lines represent the channels and dotted red lines represent the depositional lobes of the landslides' debris avalanches. Annotations 1 to 8 correspond to the numbering of the different landslides referred in the text. Arrow over lobe 1 locates shot 2350 of seismic profile Torem060. The other arrow SW of Desertas points to the landslide $\operatorname{area~}^{\circ} 5$.

Figure 6. Seismic profile Torem060 crossing the NE Madeira sector and showing a downslope gradation from almost undeformed slide-blocks located near the headscarp, to a debris avalanche characterized by chaotic facies. The central and thicker part of the debris avalanche is incised by $\mathrm{V}$-shaped channels. The sediments of the toe area seem to be slightly folded suggesting the occurrence of some compressional deformation when the debris avalanche stopped. A chaotic facies body with pinch-out and onlapped by stratified pelagic sediments can be seen in the SW sector of the seismic line suggesting the presence of a past debris flow.

Figure 7. Interpreted submarine topography: red lines represent the wave crests of the bedforms, annotation with prefix bf* represent the defined bedform fields listed in Table2, arrows point to wave fields inside channels, black straight lines and numbers next to them locate the topographic profiles of Figure 8, dark blue lines represent the headwall of the scours, and dotted black lines represent the depositional lobes of the interpreted landslides' debris avalanches.

Figure 8. Topographic profiles of the sedimentary wave-fields. 
1 Table 1. Approximate dimensions of large landslides in Madeira Archipelago

7 Table 2. Synthesis of the main morphological features of the different sediment wave fields around the islands of Madeira, Porto 8 Santo and Desertas.

\begin{tabular}{l|ll|l|l|l}
\cline { 2 - 6 } Number & Name & \multicolumn{1}{l}{ Area $\left(\mathrm{km}^{2}\right)$} & \multicolumn{1}{l}{ Length $(\mathrm{km})$} & Width $(\mathrm{km})$ & \multicolumn{1}{l}{ Type } \\
\hline 1 & NW Madeira & 1700 & 85 & 25 & Debris Flow \\
2 & NNW Madeira & 550 & 47 & 15 & Debris Flow \\
3 & NE Madeira & 500 & 35 & 20 & Debris Flow \\
4 & SE Madeira & 4000 & 110 & 45 & Debris Flow \\
5 & SW Desertas & 100 & 20 & 5 & Debris Flow \\
6 & SE Desertas & 780 & 45 & 20 & Debris Flow \\
7 & S Porto Santo & 570 & 50 & 12 & Debris Flow \\
8 & N Porto Santo & 700 & 42 & 23 & Debris Flow
\end{tabular}

\begin{tabular}{|c|c|c|c|c|c|c|c|}
\hline & Wave length $(\mathrm{m})$ & Wave height (m) & $\begin{array}{l}\text { Seafloor } \\
\text { Gradient (ㅇ) }\end{array}$ & Depth range $(\mathrm{m})$ & Cross-section & Wave crests & Comments \\
\hline bf1_shallow & $1350-1700$ & $25-35$ & 3.7 & $3000-3800$ & downslope asymmetrical & Very sinuous & debris avalanche depc \\
\hline bf1_deep & $800-3300$ & $9-42$ & $0.6-2$ & $3800-4300$ & upslope asymmetrical & Less sinous & debris avalanche depc \\
\hline bf2_shallow & $1500-2000$ & $16-32$ & 2.9 & $3000-3600$ & upslope asymmetrical & Very sinuous & unconfined flows \\
\hline bf2_deep & $1900-4800$ & $9-42$ & $0.6-1.3$ & $3600-4300$ & upslope asymmetrical & Less sinous & unconfined flows \\
\hline bf3 & $1100-4000$ & $11-94$ & $0.9-2.4$ & $3400-4000$ & downslope asymmetrical & Less sinous & debris avalanche depos \\
\hline bf4 & $1300-2400$ & $4-16$ & 1.4 & $3300-3600$ & downslope asymmetrical & crescentic upslope & debris avalanche depos \\
\hline bf5 & $600-1200$ & $2-17$ & $1.2-1.9$ & $3000-3500$ & both & crescentic downslope & inside channels \\
\hline bf6 & $1200-3000$ & $9-30$ & $0.8-1.9$ & $3400-3700$ & upslope asymmetrical & Less sinous & debris avalanche depos \\
\hline
\end{tabular}




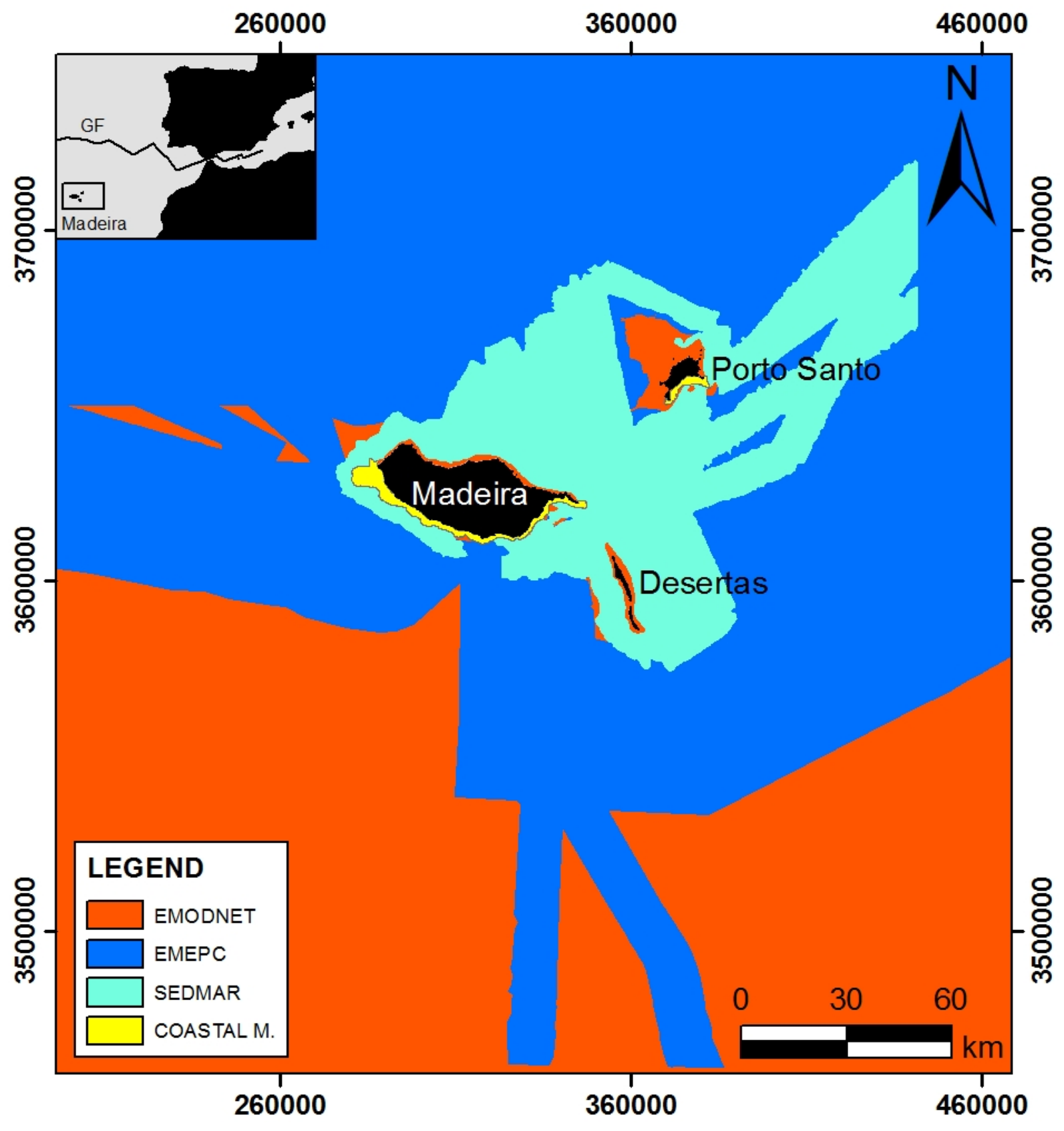




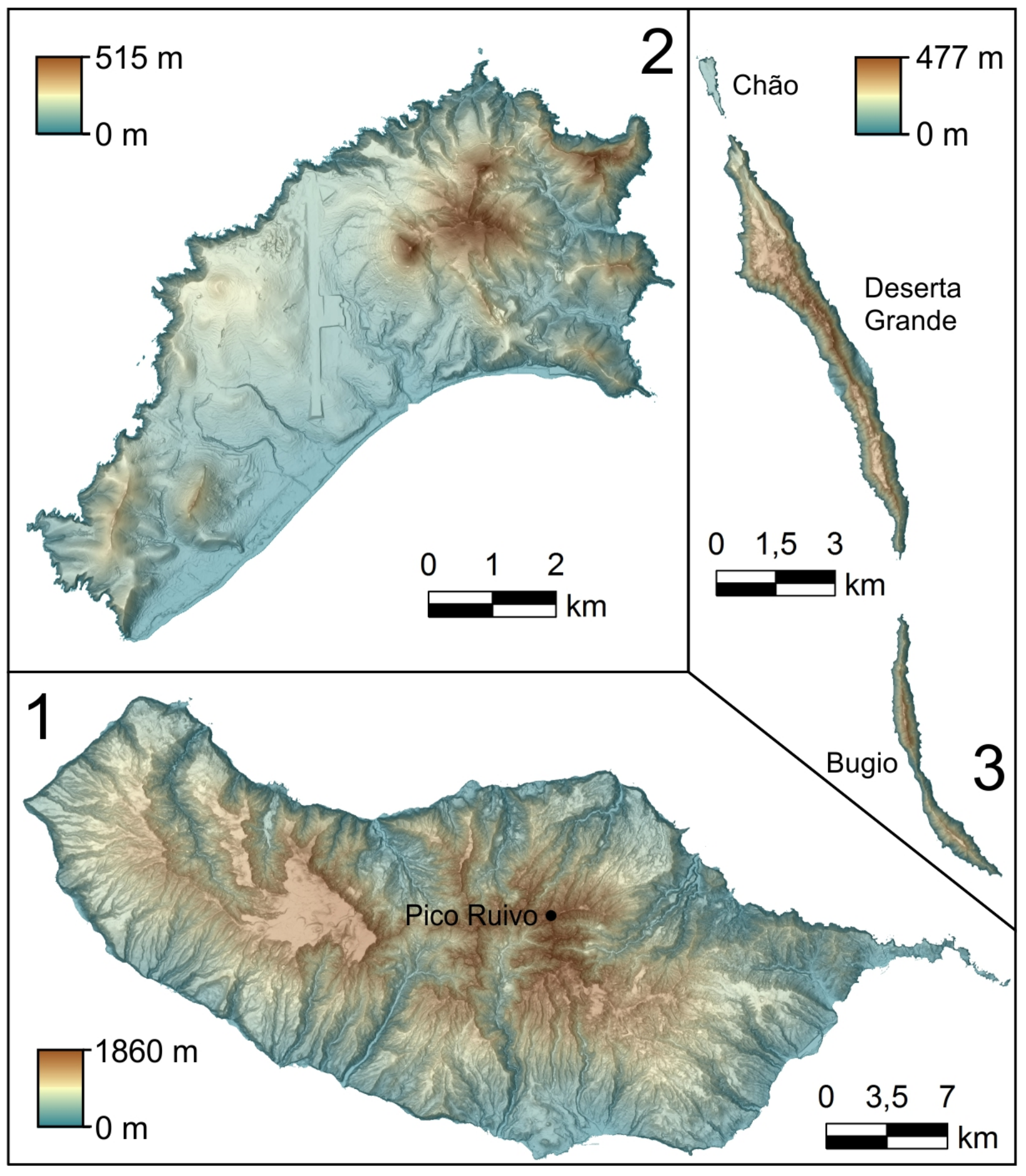




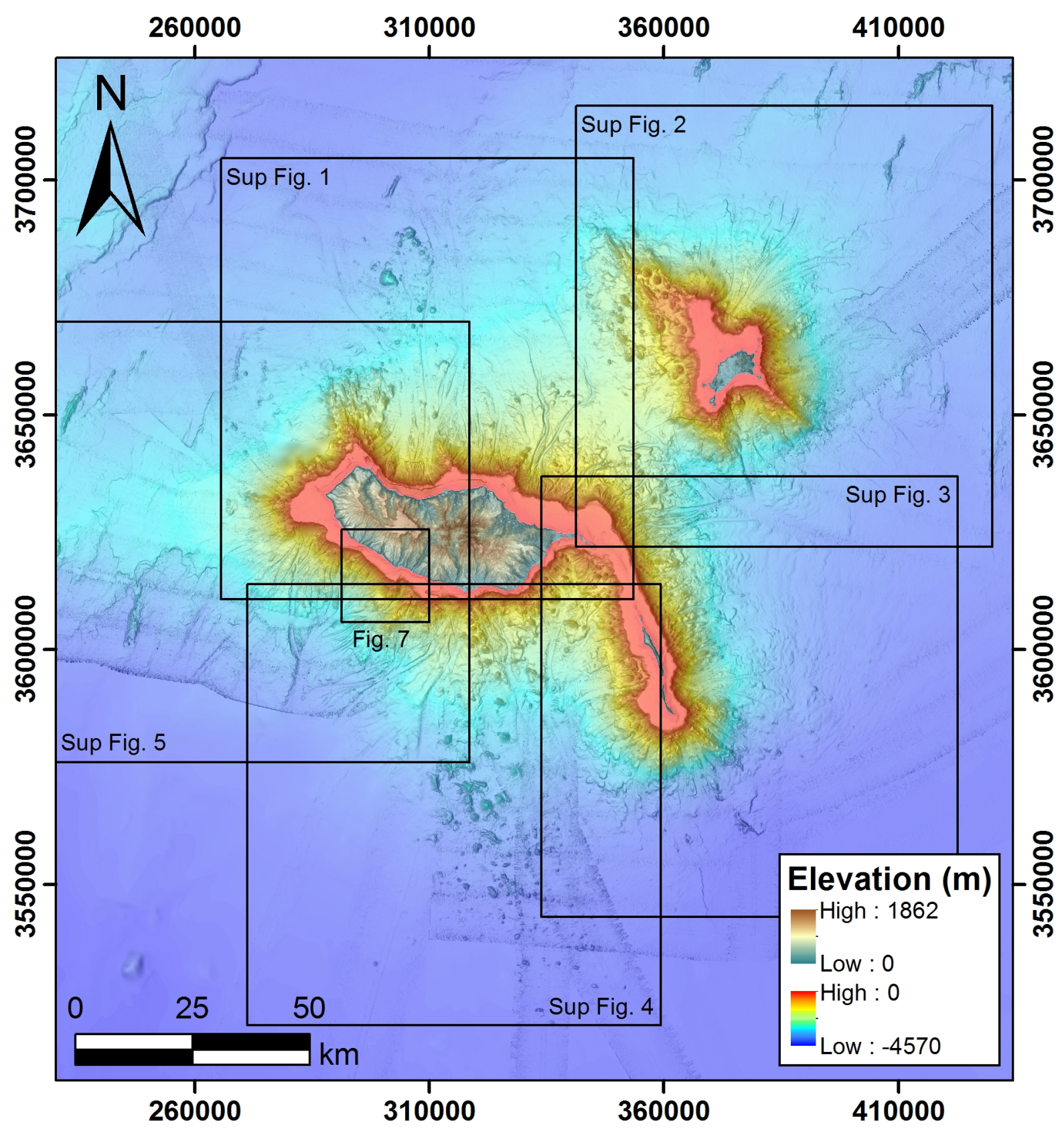




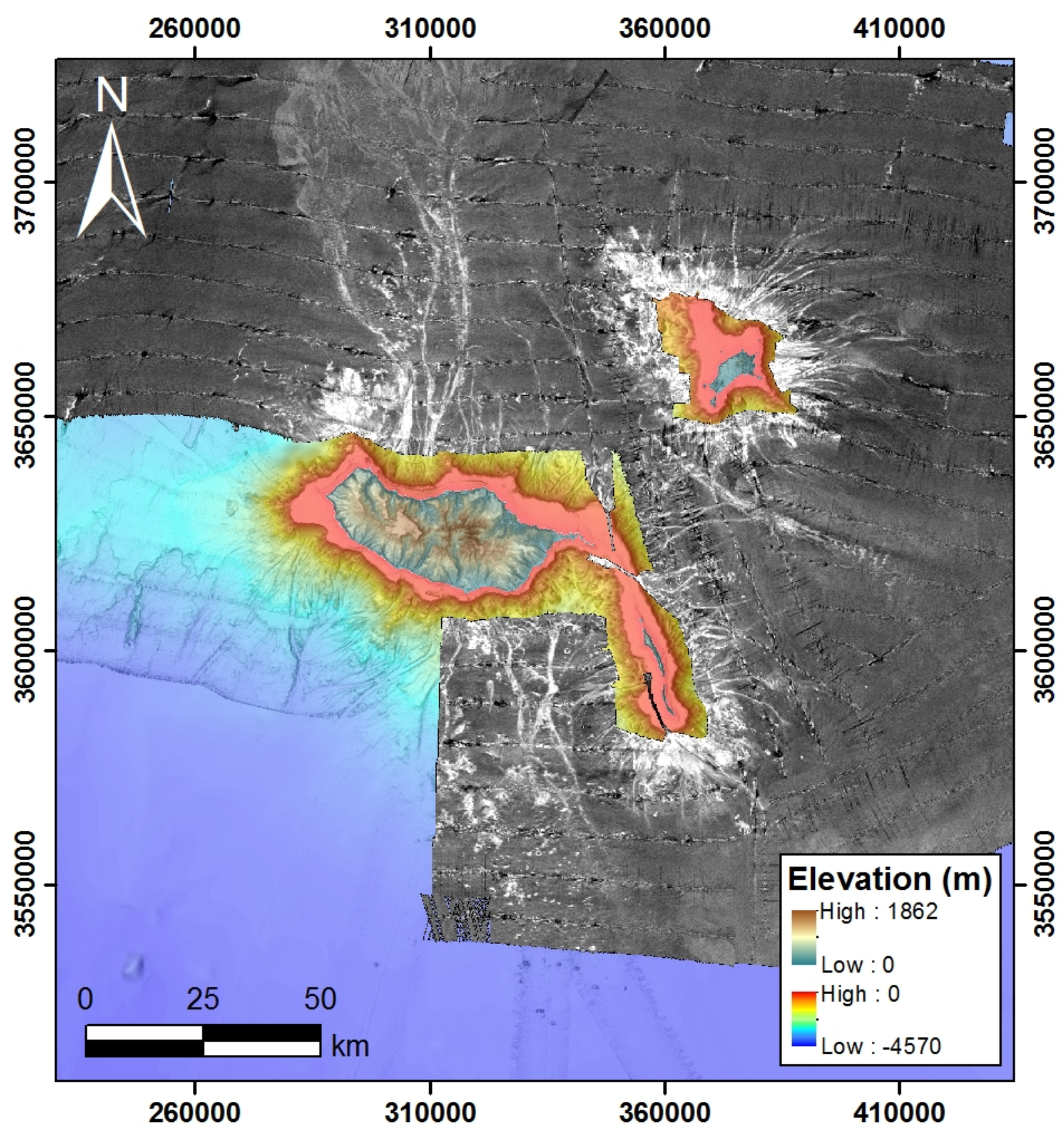




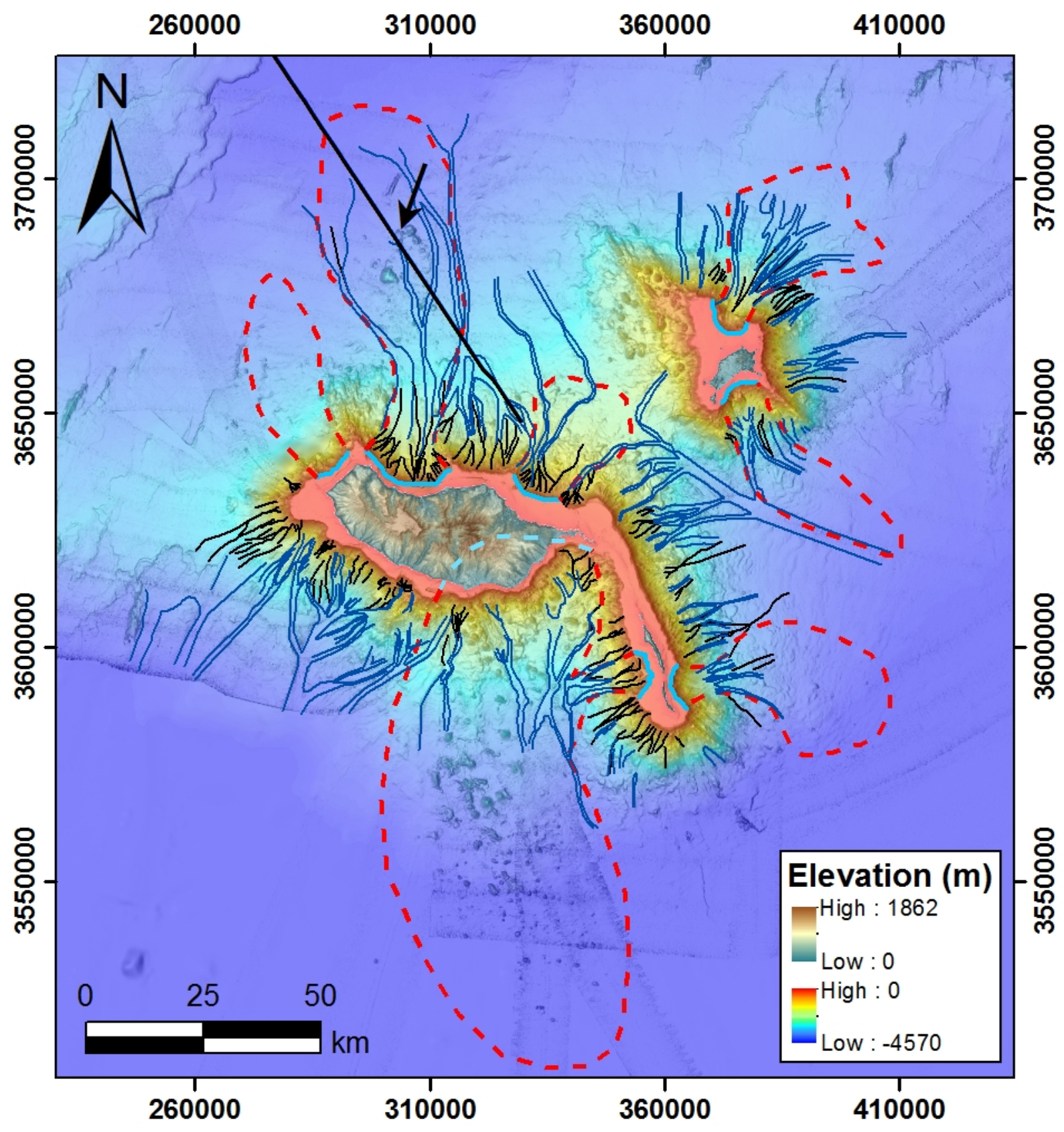




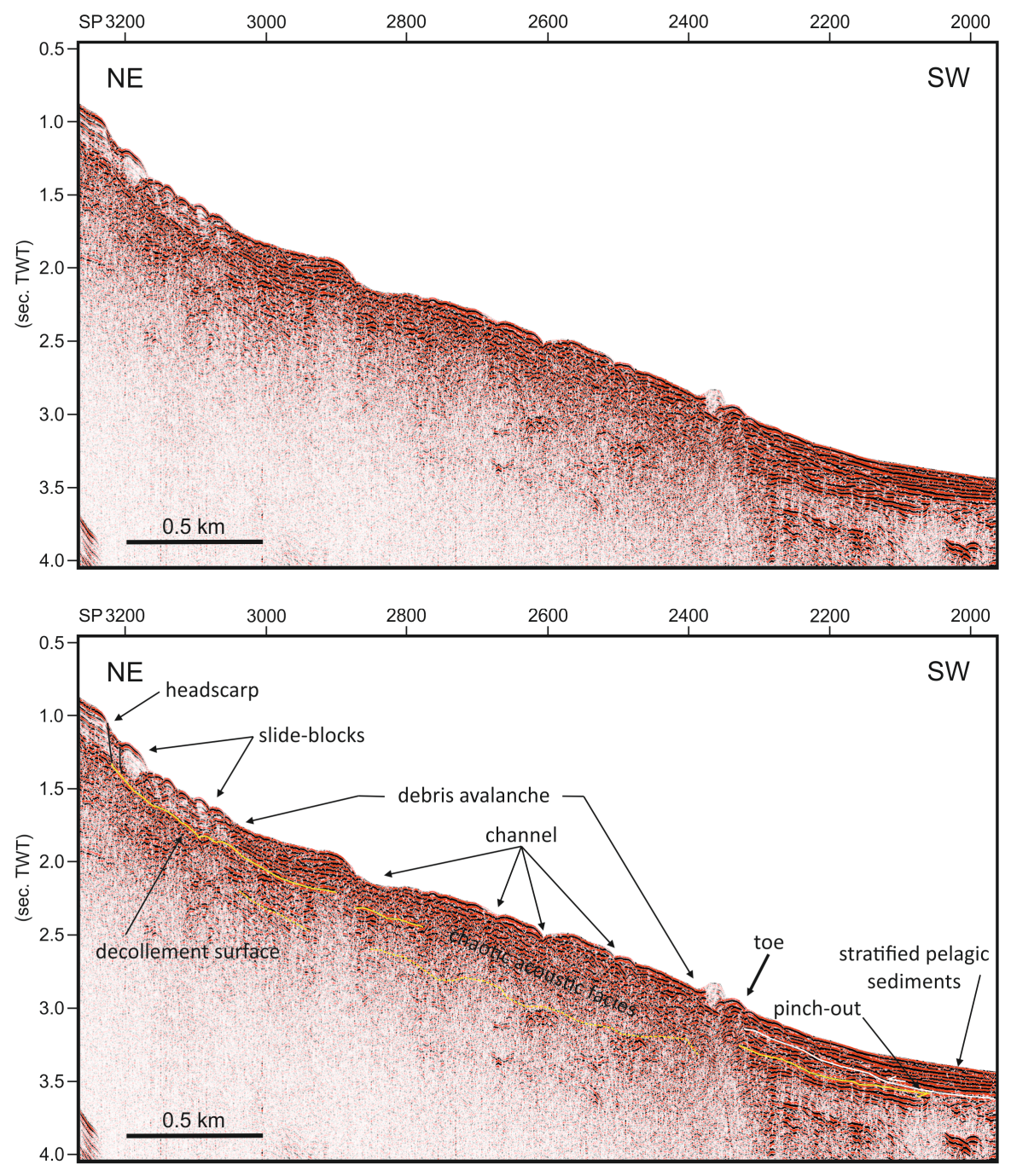




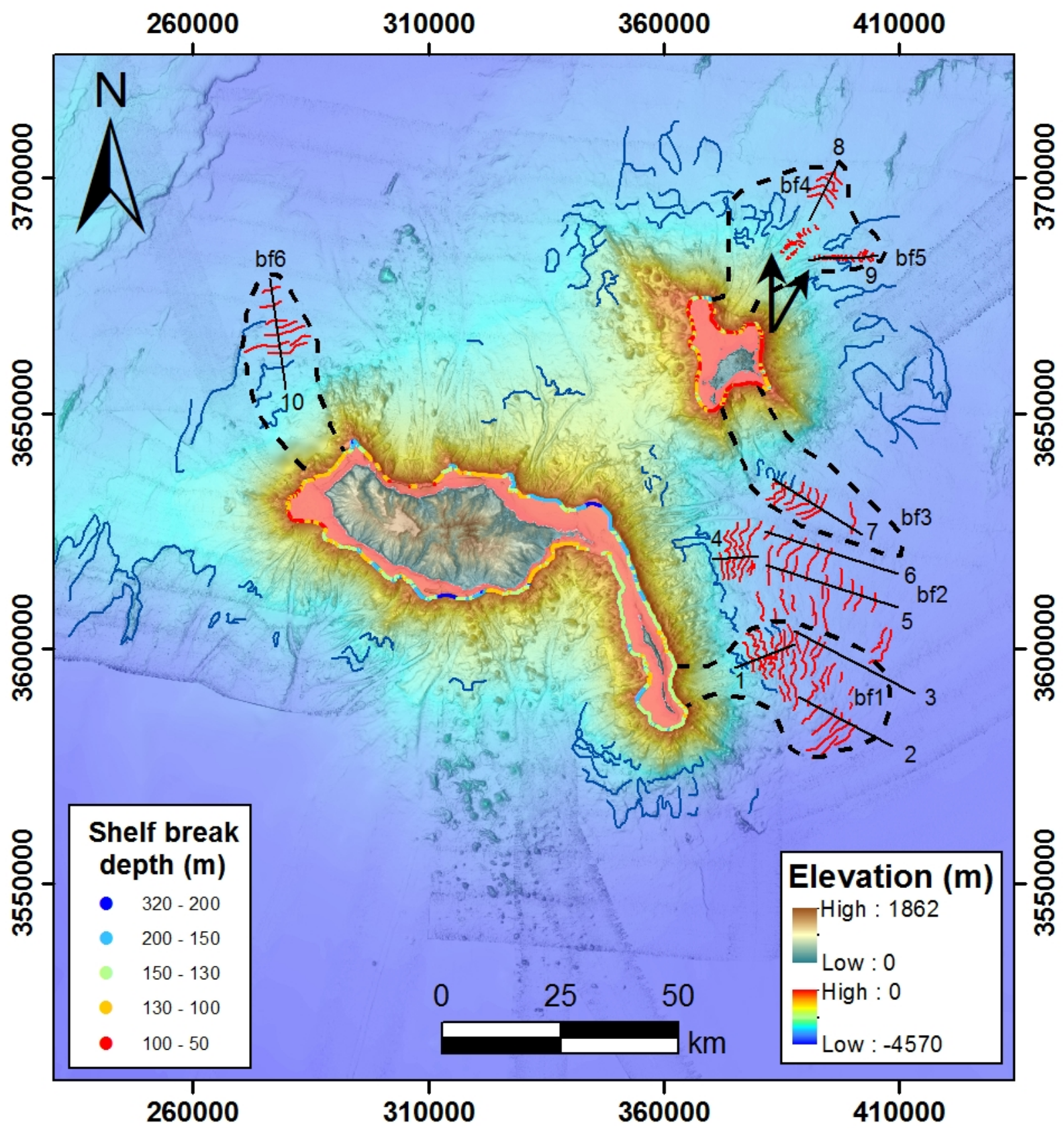




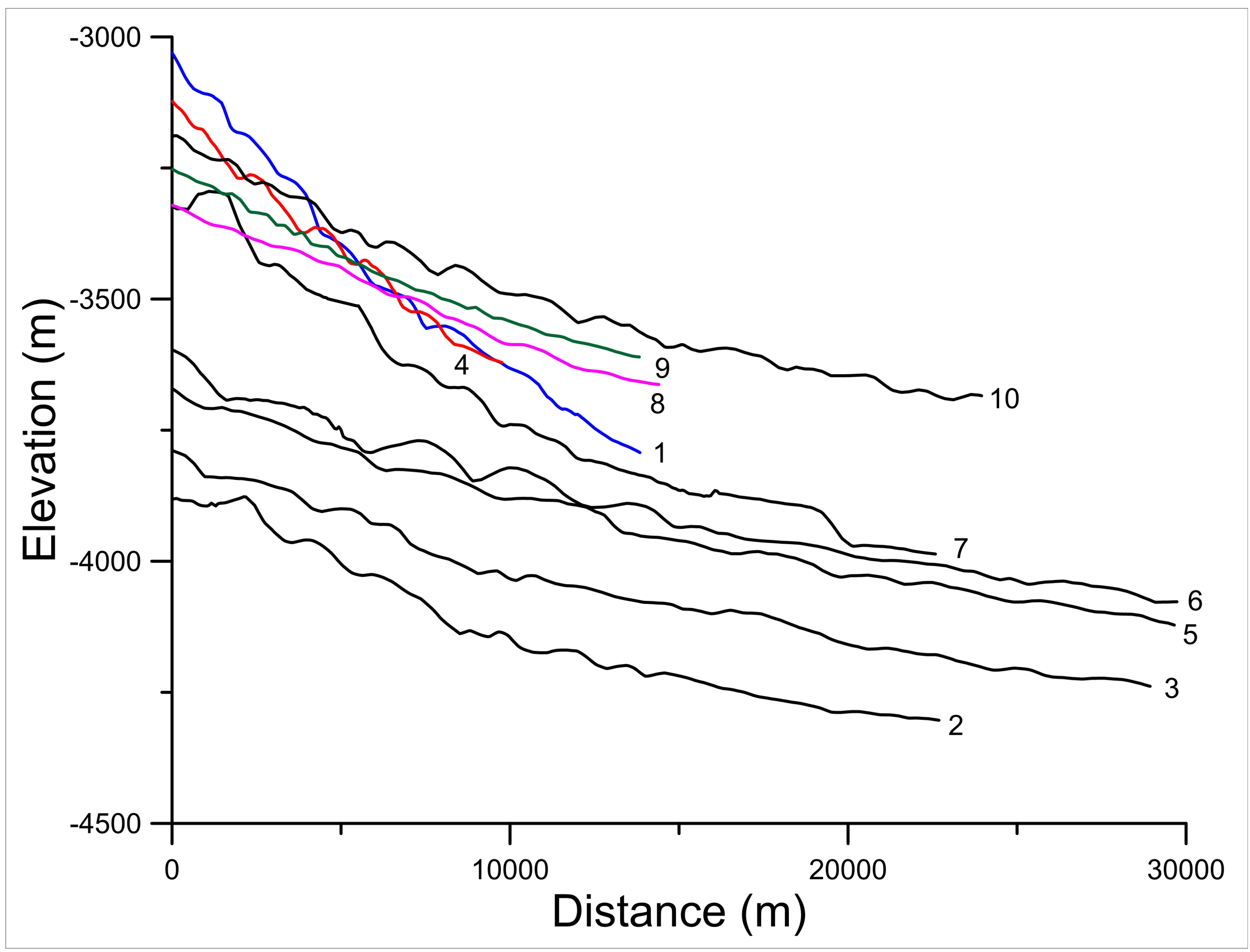




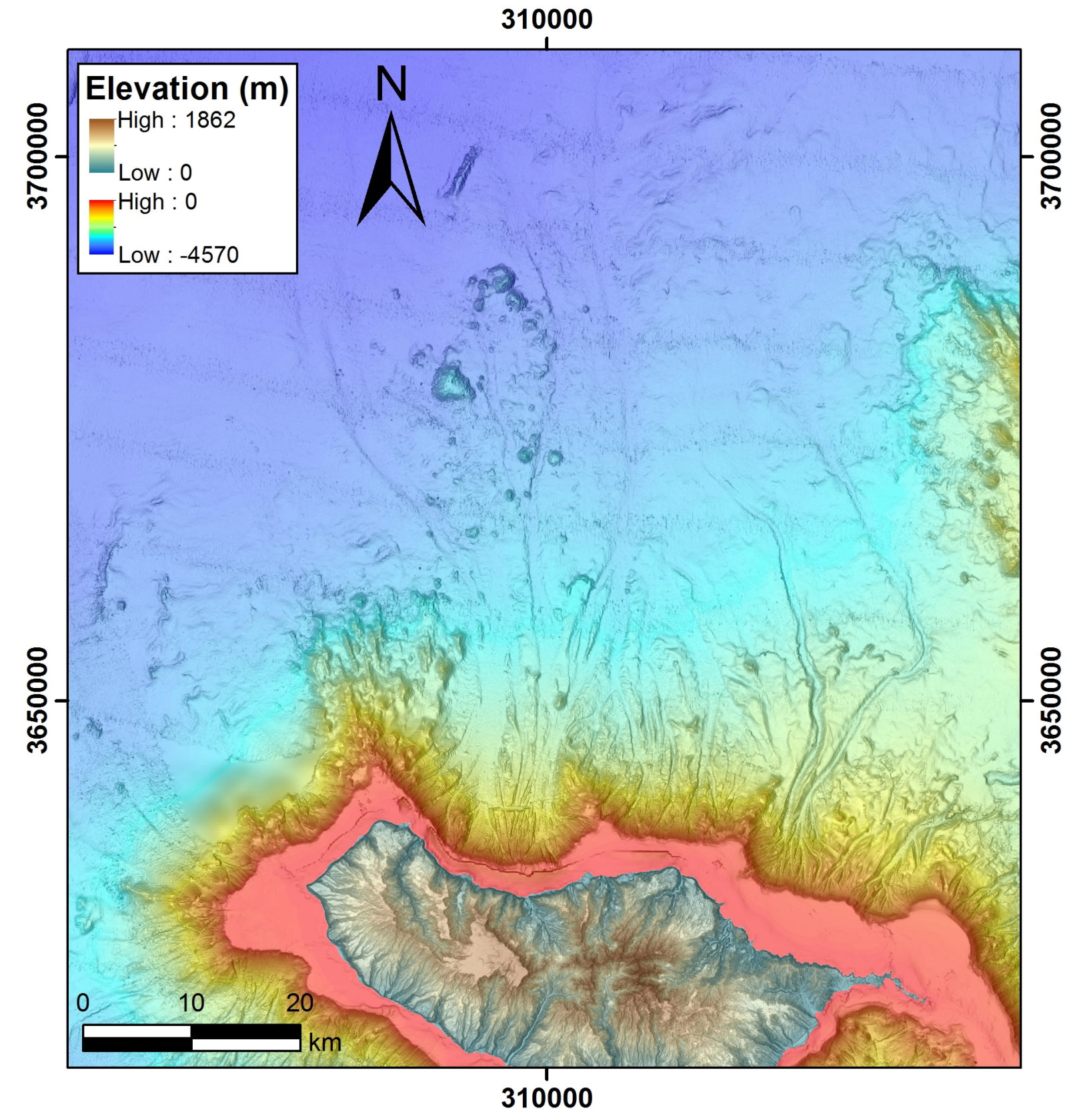




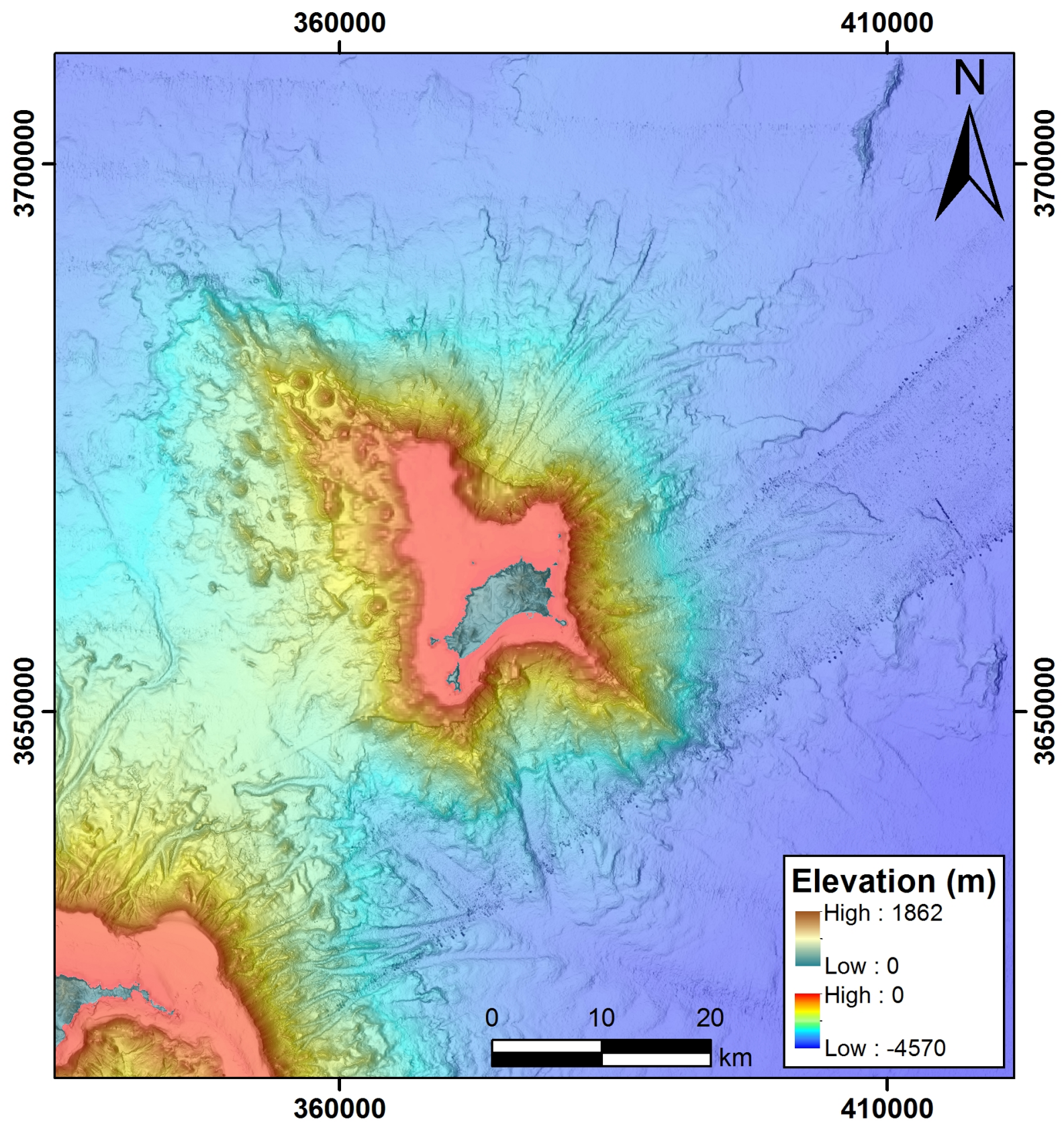




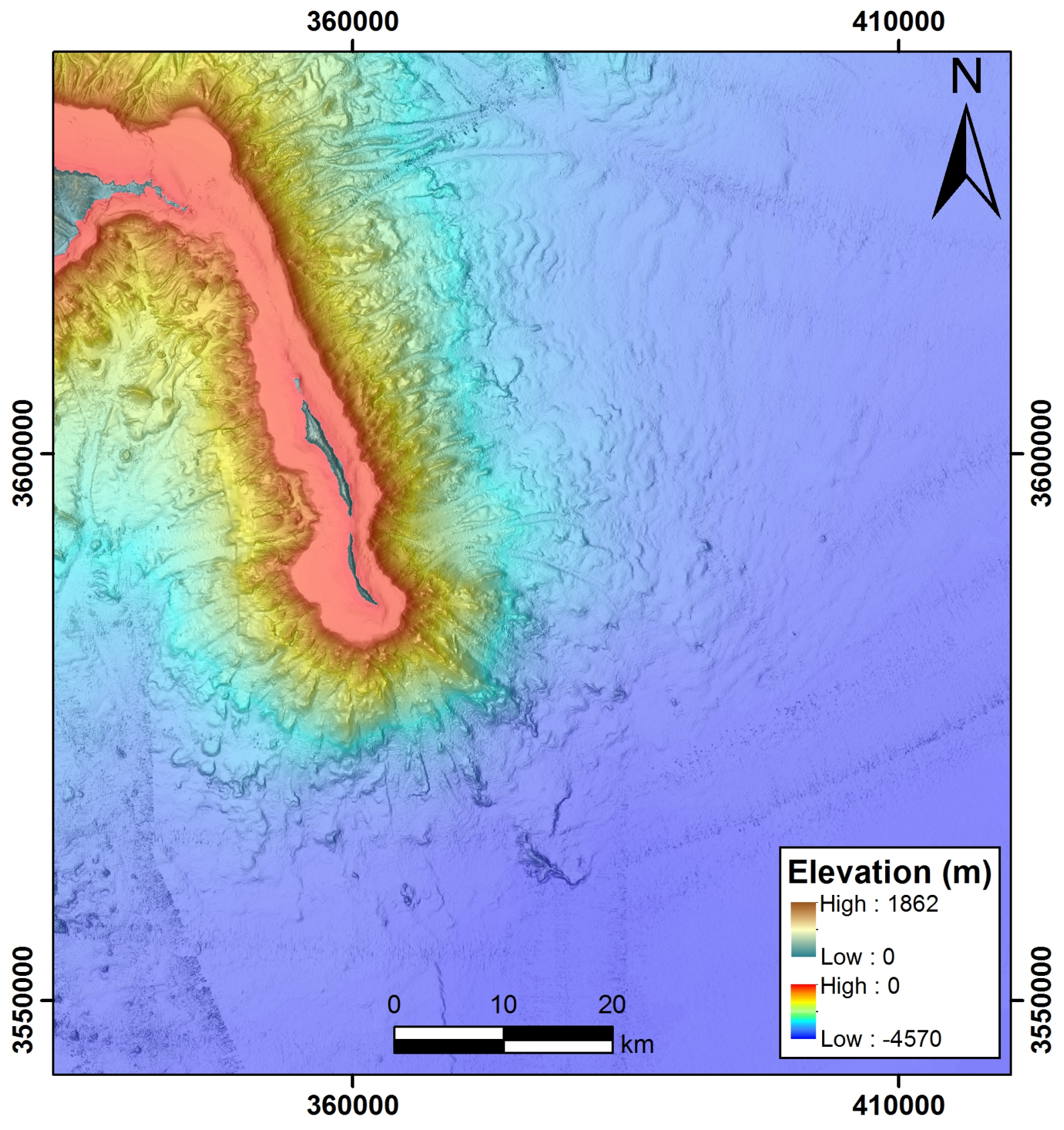




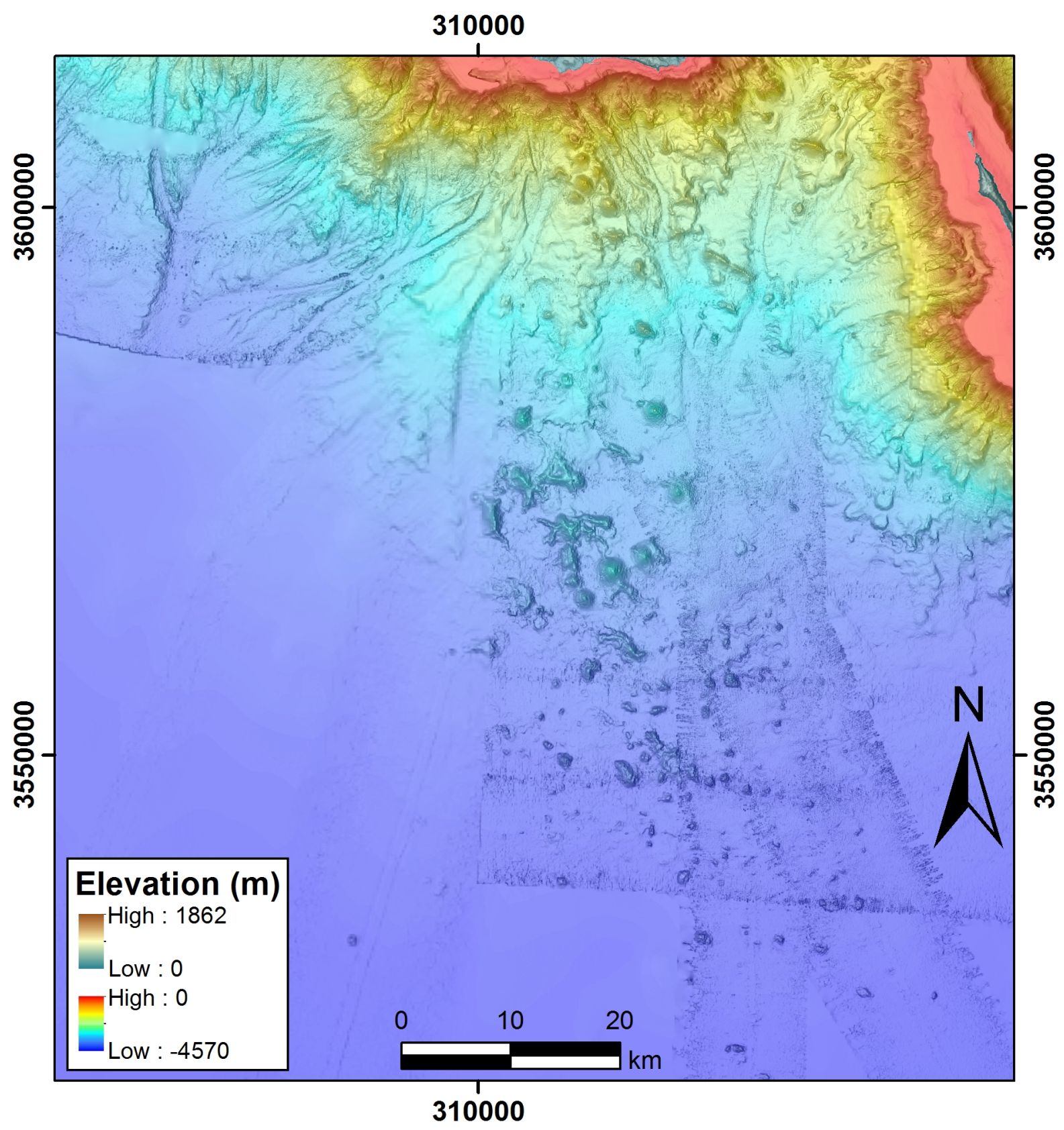




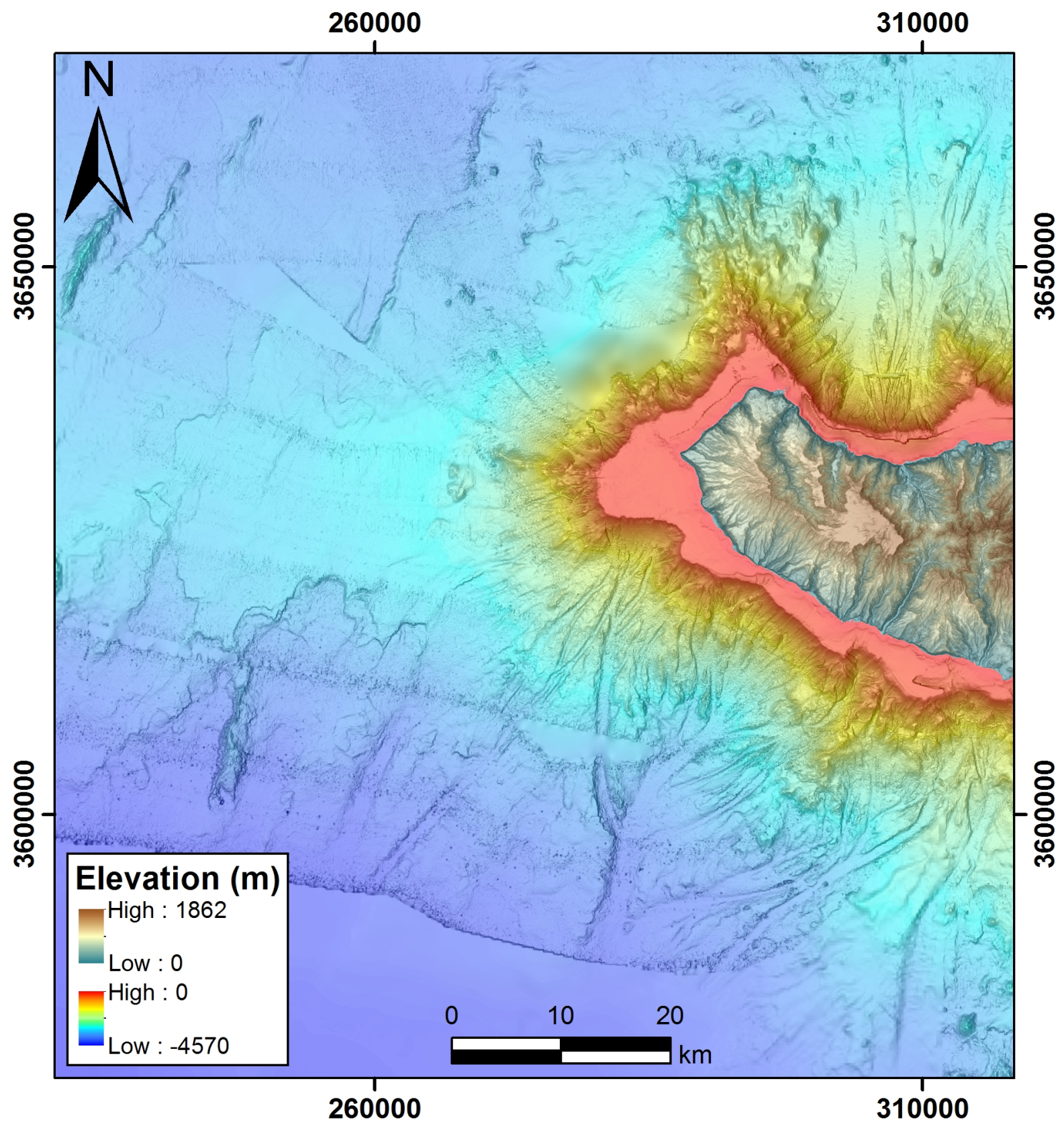

